\title{
Drought in a human-modified world: reframing drought definitions, understanding, and analysis approaches
}

\author{
Anne F. Van Loon ${ }^{1}$, Kerstin Stahl ${ }^{2}$, Giuliano Di Baldassarre ${ }^{3}$, Julian Clark ${ }^{4}$, Sally Rangecroft ${ }^{1}$, Niko Wanders ${ }^{5}$, \\ Tom Gleeson $^{6}$, Albert I. J. M. Van Dijk ${ }^{7}$, Lena M. Tallaksen ${ }^{8}$, Jamie Hannaford ${ }^{9}$, Remko Uijlenhoet ${ }^{10}$, \\ Adriaan J. Teuling ${ }^{10}$, David M. Hannah ${ }^{1}$, Justin Sheffield ${ }^{5}$, Mark Svoboda ${ }^{11}$, Boud Verbeiren ${ }^{12}$, \\ Thorsten Wagener ${ }^{13,14}$, and Henny A. J. Van Lanen ${ }^{10}$ \\ ${ }^{1}$ Water Science Research Group, School of Geography, Earth, and Environmental Sciences, University of Birmingham, \\ Edgbaston, Birmingham, UK \\ ${ }^{2}$ Hydrology Department, Faculty of Environment and Natural Resources, University of Freiburg, Freiburg, Germany \\ ${ }^{3}$ Department of Earth Sciences, Uppsala University, Uppsala, Sweden \\ ${ }^{4}$ Human Geography Research Group, School of Geography, Earth, and Environmental Sciences, University of Birmingham, \\ Birmingham, UK \\ ${ }^{5}$ Civil and Environmental Engineering, Princeton University, Princeton, NJ, USA \\ ${ }^{6}$ Department of Civil Engineering, University of Victoria, Victoria, Canada \\ ${ }^{7}$ Fenner School of Environment \& Society, the Australian National University, Canberra, Australia \\ ${ }^{8}$ Department of Geosciences, University of Oslo, Oslo, Norway \\ ${ }^{9}$ Centre for Ecology and Hydrology, Wallingford, UK \\ ${ }^{10}$ Hydrology and Quantitative Water Management group, Wageningen University, Wageningen, the Netherlands \\ ${ }^{11}$ National Drought Mitigation Center, University of Nebraska, Lincoln, NE, USA \\ ${ }^{12}$ Department of Hydrology and Hydraulic Engineering, Vrije Universiteit Brussel, Brussels, Belgium \\ ${ }^{13}$ Department of Civil Engineering, University of Bristol, Bristol, UK \\ ${ }^{14}$ Cabot Institute, University of Bristol, Bristol, UK
}

Correspondence to: Anne F. Van Loon (a.f.vanloon@bham.ac.uk)

Received: 20 May 2016 - Published in Hydrol. Earth Syst. Sci. Discuss.: 31 May 2016

Revised: 23 August 2016 - Accepted: 26 August 2016 - Published: 8 September 2016

\begin{abstract}
In the current human-modified world, or Anthropocene, the state of water stores and fluxes has become dependent on human as well as natural processes. Water deficits (or droughts) are the result of a complex interaction between meteorological anomalies, land surface processes, and human inflows, outflows, and storage changes. Our current inability to adequately analyse and manage drought in many places points to gaps in our understanding and to inadequate data and tools. The Anthropocene requires a new framework for drought definitions and research. Drought definitions need to be revisited to explicitly include human processes driving and modifying soil moisture drought and hydrological drought development. We give recommendations for robust drought definitions to clarify timescales of drought and
\end{abstract}

prevent confusion with related terms such as water scarcity and overexploitation. Additionally, our understanding and analysis of drought need to move from single driver to multiple drivers and from uni-directional to multi-directional. We identify research gaps and propose analysis approaches on (1) drivers, (2) modifiers, (3) impacts, (4) feedbacks, and (5) changing the baseline of drought in the Anthropocene. The most pressing research questions are related to the attribution of drought to its causes, to linking drought impacts to drought characteristics, and to societal adaptation and responses to drought. Example questions include 
(i) What are the dominant drivers of drought in different parts of the world?

(ii) How do human modifications of drought enhance or alleviate drought severity?

(iii) How do impacts of drought depend on the physical characteristics of drought vs. the vulnerability of people or the environment?

(iv) To what extent are physical and human drought processes coupled, and can feedback loops be identified and altered to lessen or mitigate drought?

(v) How should we adapt our drought analysis to accommodate changes in the normal situation (i.e. what are considered normal or reference conditions) over time?

Answering these questions requires exploration of qualitative and quantitative data as well as mixed modelling approaches. The challenges related to drought research and management in the Anthropocene are not unique to drought, but do require urgent attention. We give recommendations drawn from the fields of flood research, ecology, water management, and water resources studies. The framework presented here provides a holistic view on drought in the Anthropocene, which will help improve management strategies for mitigating the severity and reducing the impacts of droughts in future.

\section{Introduction}

The hydrological system is intrinsically intertwined with the climate system, the environmental/ecological system and the social system (Fig. 1). These links are dynamic and interdependent. Natural water inflows and outflows vary and change in time and space, as do human water exploitation and associated activities, leading to what some have called a mutually co-evolving hydrosocial cycle (Linton and Budds (2014), p. 170). All these complex interlinked processes define the state of the hydrological system and the amount of water stored in the soil, groundwater, lakes, rivers, and reservoirs. When there is (much) less water in the hydrological system than normal, as manifested in below-normal soil moisture levels, river discharge, groundwater, and/or lake/reservoir levels, the system is perceived to be in drought, whether by natural causes (meteorological anomalies) or anthropogenic causes such as groundwater abstraction (Van Loon et al., 2016). Droughts can have severe consequences for water use in various sectors, for instance agriculture, drinking water supply and hydropower production, as well as adverse impacts on ecosystems (Ciais et al., 2005; Lake, 2011; Sheffield et al., 2012; Grayson, 2013; Mosely, 2015; Stahl et al., 2015, 2016).

In recent decades, droughts have received increasing attention from policy makers and society, while drought research

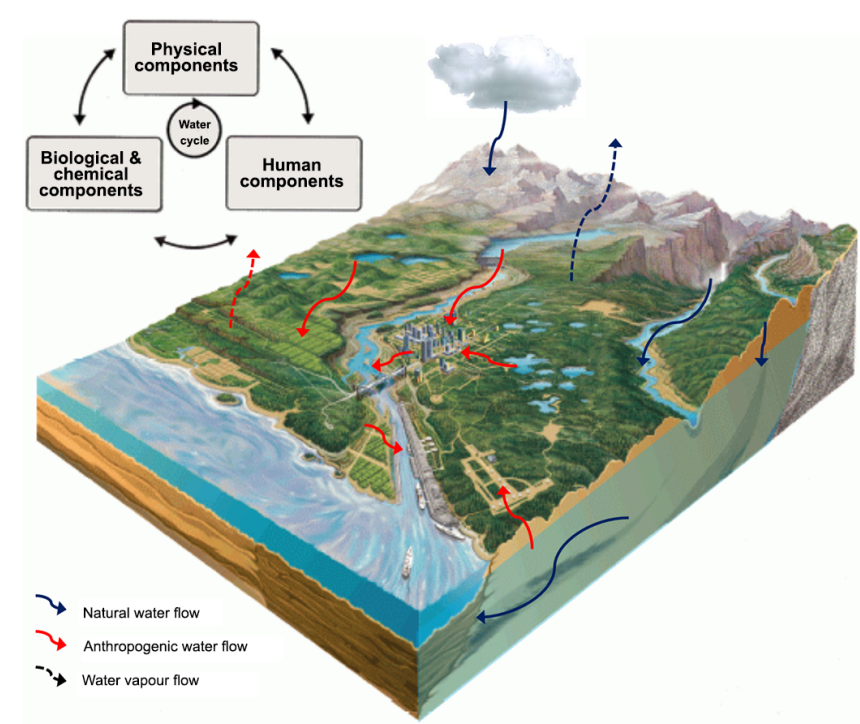

Figure 1. The water system linking physical, biological, and human components through natural and anthropogenic water flows (adapted from Winter et al., 1998; Vörösmarty et al., 2004; copyright: AGU).

has made significant progress. Examples of this progress are the continuous development of drought indices (Shukla and Wood, 2008; Bloomfield and Marchant, 2013; Stagge et al., 2015b); the improved understanding of the link between drought and atmospheric and ocean drivers (Fleig et al., 2010; Kingston et al., 2015); the influence of evapotranspiration (Teuling et al., 2013), snow (Staudinger et al., 2014) and geology (Stoelzle et al., 2014; Kumar et al., 2016) on drought severity; drought monitoring and forecasting (Sheffield et al., 2014; Trambauer et al., 2015); and the effects of climate change on drought (Prudhomme et al., 2014; Trenberth et al., 2014; Wanders et al., 2015).

Still, many challenges remain. For example, the attribution of a groundwater or surface water deficit to its natural and human causes and the prediction of such a drought remain very difficult (Van Dijk et al., 2013; Diffenbaugh et al., 2015). For the recent multi-year drought in California this has led to discussion about the role of groundwater abstraction (AghaKouchak et al., 2015a). Additionally, observed trends in measured low flows and drought are influenced by human activities (Sadri et al., 2016), probably even when only unregulated catchments are selected (as noted by Hisdal et al., 2001; Stahl et al., 2010). This undermines our understanding of the effects of climate change on low flows and droughts and increases the uncertainty in projections for the future (Forzieri et al., 2014). Similar difficulties arise when attempting to link physical (i.e. climate or hydrological) indicators with societal or environmental impacts (Stanke et al., 2013; Bachmair et al., 2015; Gudmundsson et al., 2014; Blauhut et al., 2015; Stagge et al., 2015a), with this link being a crucial step in enabling societies to prepare for drought risks. In many big 


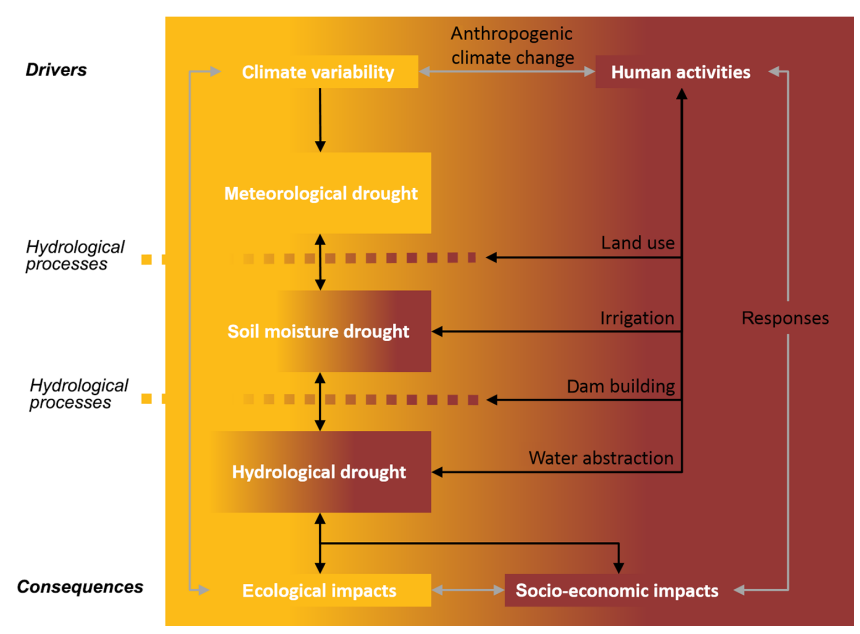

Figure 2. Drought propagation including natural and human drivers and feedbacks; black arrows indicate direct influences and grey arrows indicate feedbacks (modified from Van Loon et al., 2016).

cities, for example, coping with drought is very complex, because vulnerability is high and factors such as the urban heat island effect, poor water supply, and water quality issues play an additional role (Güneralp et al., 2015). In drought management, the connections within the hydrological cycle are often overlooked, for example, when unsustainable groundwater abstraction is used as adaptation to drought (e.g. Castle et al., 2014; Foster et al., 2015), or when restrictions are imposed for using surface water, but not for groundwater, leading to enhancement of the hydrological drought (as during the recent California drought and previous droughts in the Netherlands).

These examples point out a number of issues (see Box 1). Firstly, recent (drought) research is not always picked up by water managers and policy makers. There exists a lack of two-way communication between stakeholders and researchers, with proper ontology and semantics. Secondly, drought research itself has some important gaps related to the interplay between drought and humans, which prevent us from completely understanding the complex interdisciplinary issue that is drought. Thirdly, these examples also highlight the unsuitability of current methods and data to address these gaps. For successful drought risk management, our understanding must include the processes leading to drought (causes) and the impacts of drought (consequences). In this way, drought predictions can be made and effective measures taken to mitigate drought severity and to reduce drought impacts.

The growing human impact on the earth system has led to numerous calls to recognize a new, distinct geological epoch: the Anthropocene. While debate continues about the definition of the Anthropocene (Crutzen, 2002; Lewis and Maslin, 2015; Hamilton, 2016), it provides a useful framework for considering the present era, when human activity plays a fun- damental role in water, energy, and biogeochemical cycles. In the Anthropocene, society actively shapes water availability, and the feedbacks between physical and social aspects are particularly important during periods of water deficit. This means we cannot see drought as an external natural hazard and treat the consequences separately from the causes. Van Loon et al. (2016) argued that, for successful drought management in the Anthropocene, natural and human processes need to be fully integrated into drought definitions, process understanding, and analysis approaches. This paper builds on that argument and elaborates on research questions, data, and methodology that are needed to reframe and extent drought research in the Anthropocene.

\section{Drought definitions in the Anthropocene}

It is known that human activities can create a drought situation or make an existing one worse (e.g. Wilhite and Glanz, 1985; Tallaksen and Van Lanen, 2004), but these processes are rarely ever explicitly included in drought definitions. Much has been said about the need for objective drought definitions and the difficulties related to that aim (e.g. Yevjevich, 1967; Wilhite and Glantz, 1985; Lloyd-Hughes, 2014), which we will not repeat here. We do, however, need to have a closer look at identifying the role of human processes in the definition of drought. In this section, we therefore revisit drought definitions and make suggestions for robust use in the Anthropocene.

\subsection{Drought as a lack of water}

Drought is defined as a lack of water compared to normal conditions which can occur in different components of the hydrological cycle (Palmer, 1965; Tallaksen and Van Lanen, 2004; Sheffield and Wood, 2011). It is commonly subdivided into meteorological drought (rainfall deficit), soil moisture drought (below-normal soil moisture levels), and hydrological drought (below-normal (sub)surface water availability). The normal is often taken as a percentile of the climatology of the variable of interest, and severity (e.g. deficit volume) and duration of drought events can be calculated (Van Loon, 2015).

In the natural sciences, there is a fair understanding of the propagation of drought from meteorological drought to soil moisture drought and hydrological drought (Fig. 2, left side), influenced by catchment properties such as geology and vegetation cover. For example, many hydrological drought types have been recognized, e.g. the classical rainfall-deficit drought, but also hydrological droughts caused by temperature anomalies in snow-dominated areas (Van Loon and Van Lanen, 2012; Van Loon et al., 2015). This is typically regarded as a uni-directional propagation with human receptors at the downstream end. However, in reality, human processes are interlinked with natural processes in various ways (Fig. 2, 


\section{Drought management: Rhine (the Netherlands)}

In the Netherlands, drought management measures and National Drought Committee meetings start when the discharge of the river Rhine falls below a pre-defined level, independent of possible causes of the low river flows (e.g. lack of rainfall, lack of snow melt, Germany abstracting more water; Rijkswaterstaat, 2015).

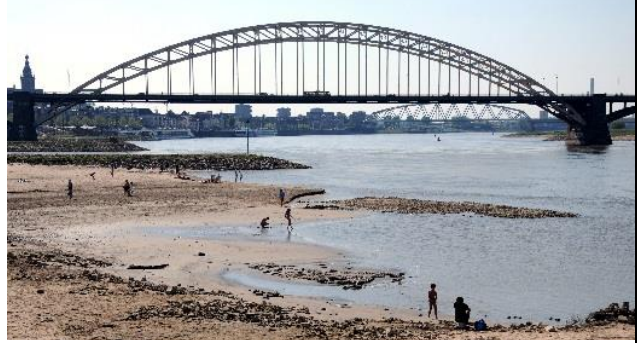

Figure B 1: 2011 drought on the River Rhine near Nijmegen (photo Ronald Puma; ronaldpuma.nl)

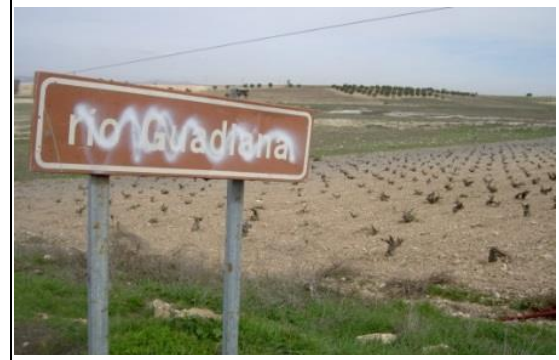

Figure B 2: Name of Guadiana River crossed out after being dry for 20 years.

\section{Drought attribution: Upper-Guadiana (Spain)}

An important wetland dried up in Spain in the 1990s. Nature organizations blamed the abstraction for irrigation by farmers, but farmers pointed to the severe multi-year lack of rainfall. There was a need to attribute the low water levels to their causes. Modelling showed that both parties were right, but that abstraction had 4 times as much influence than the lack of rainfall (Van Loon and Van Lanen, 2013).

\section{Drought termination: California (USA)}

"How much rainfall is needed to end the drought?" This question was and still is often mentioned in the media in California. We can calculate how much rain is needed to fill up the system, but at the same time we are constantly taking water out (for example, by groundwater abstraction) and putting water in (for example, by water transfers). Those human inputs and outputs cannot be disregarded in the calculation of how much rain is needed to end the drought.

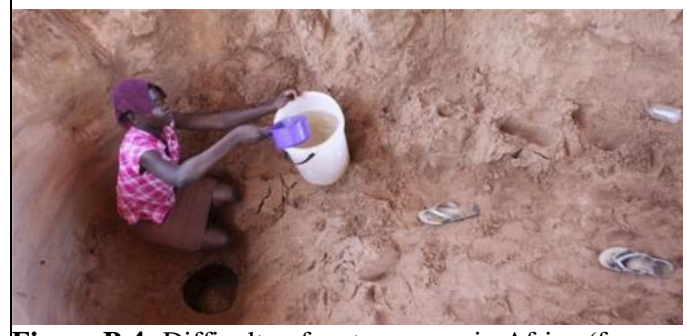

Figure B 4: Difficulty of water access in Africa (from www.ghanaweb.com/GhanaHomePage/world/SouthAfrica-won-t-declare-national-disaster-over-drought413602, last access 13 May 2016)

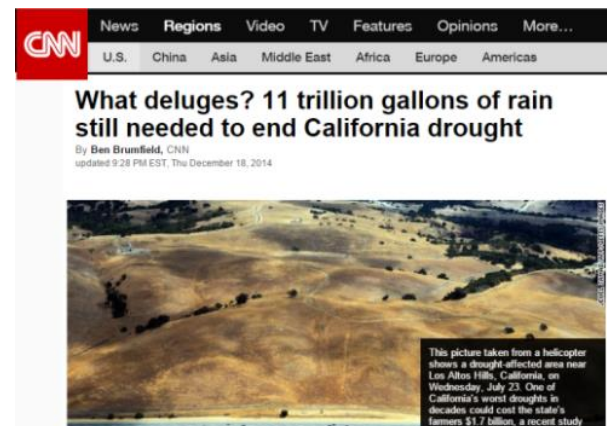

Figure B 3: Media trying to answer the question how much rain is needed to end California drought (from edition.cnn.com/2014/12/18/us/californiarains-and-drought, last access 13 Mav 2016)

\section{Drought impacts: Africa}

The impacts of drought are not only related to the severity of drought, but also to access to water sources, and possibility of using alternative sources. Most communities in Africa are very dependent on rain water and do not have access to alternative sources such as groundwater. A lack of rain then leads to severe impacts, even though groundwater reserves and nearby river basins might not suffer from drought (yet).

Box 1. Examples of why humans are integral to drought and we should not focus on natural drought causes only. 


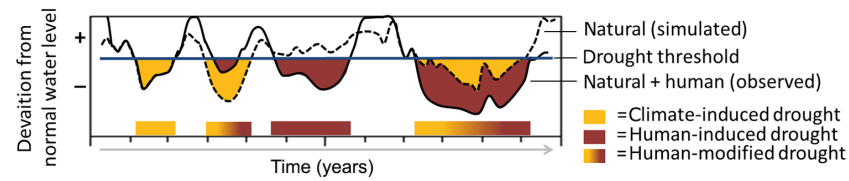

Figure 3. Drought types: climate-induced drought, human-induced drought, human-modified drought (modified from Van Loon et al., 2016).

right side). Soil moisture and hydrological drought (hereafter called drought) are the result of low inputs to the hydrological system (e.g. lack of rain, snow/glacier melt, irrigation, sewage return flows), high outputs (e.g. evapotranspiration, human water use), and limited storage (in soil, groundwater, lakes, and reservoirs). Human activities influence water input, output, and storage and therefore modify the propagation of drought and can even be the cause of drought in the absence of natural drivers of drought. The drought typology based on natural processes should therefore be complemented with drought types based on human processes.

The natural drought types can be grouped together as "climate-induced" droughts and drought types based on human processes can be termed "human-induced" or "manmade" drought (Fig. 3; Van Loon et al., 2016). This parallels an existing widely referenced typology of floods, which includes man-made flood alongside natural floods such as flash flood, snowmelt flood, and ice jam flood (e.g. Yevjevich, 1994; De Kraker, 2015). The distinction between climateinduced and human-induced drought is useful in studies of the attribution of drought to its causes. To further acknowledge the possibly large influence of human activities modifying drought (Fig. 2), we additionally propose the term "human-modified drought" for a drought that is enhanced or alleviated as the result of anthropogenic processes (Fig. 3). For this terminology, we focus on direct human influences on the hydrological cycle such as water abstraction and land use change, although we recognize that anthropogenic climate change indirectly affects the meteorological drivers of drought (e.g. Williams et al., 2015).

With these terms, we actively include humans as drivers and modifiers of drought in the definition. There is no need for rephrasing the general drought definition, in which human processes are implicitly included. Furthermore, the terms we propose are not new (climate-induced drought: Sheffield and Wood, 2011, p. 30; human-induced drought: Wilhite and Buchanan-Smith 2005, p. 10 and Falkenmark and Rockström, 2008, p. 93) and they match well with the flood terminology (Yevjevich, 1994).

\subsection{Drier than normal: timescales of drought in the Anthropocene}

Drought is a lack of water compared to a certain normal situation, but what constitutes this normal situation in the An- thropocene? A drought occurs when actual water availability (indicated by water levels or fluxes) is below normal (Fig. 4). In a natural catchment, undisturbed by human activity, both actual and normal water availability are governed by natural processes in response to climate. Normal water availability is determined by the climate (long timescales), for example, a (semi-)arid climate results in low average water availability (aridity; Table 1) and low threshold levels (Fig. 4c). Actual availability is determined by climate variability (here used as term for a combination of weather events; short timescales); for example, a rainfall deficit leading to a climate-induced drought (Table 1; Fig. 4a, c). Even though drought is defined on shorter timescales than aridity, very short periods of below-normal water availability are often not regarded as drought, e.g. drought is defined as "sustained" by Tallaksen and Van Lanen (2004, p. 4), which means it lasts for longer than few days. This makes droughts generally occur on longer timescales than, for example, floods.

In a human-influenced catchment, actual and normal water availability are, besides by climate, also influenced by human activities (Fig. 4b, d). The actual situation is influenced by water use and water management (short timescales), leading to lower or higher water levels, whereas the normal situation is influenced by long-term actions such as groundwater depletion and anthropogenic land use change (long timescales; Table 1). There are different ways to account for this different normal. If we have a long-enough time series to determine the normal situation as influenced by human activities, we can use that as our reference or threshold and only determine our droughts as extreme events relative to this humaninfluenced normal (Fig. 4b, d: disturbed drought threshold). For example, in the Júcar Basin in Spain drought measures are based on thresholds in measured reservoir levels, groundwater levels, and river flow, which are all heavily influenced by abstraction for irrigation (Andreu et al., 2009). Alternatively, we can use a threshold determined from an undisturbed period or a naturalized model scenario, so using the situation that would have occurred without human activities as reference, as a natural normal (Fig. 4b, d: natural drought threshold; e.g. Van Loon and Van Lanen, 2013). The latter allows for a better identification of human-modified drought, both droughts enhanced and alleviated by human activities (Van Loon and Van Lanen, 2015). Because drought is an extreme event, the normal situation is not characterized by long-term average water levels or fluxes. Instead, a drought threshold (Fig. 3) is used that is calculated as a percentile(s) of a long time series (commonly, the value that is exceeded $80-95 \%$ of the time) or return periods representing rare occurrence (for example, a 50-year drought). Some studies use a variable threshold calculated on daily, monthly, or seasonal timescales to represent seasonality and identify differences between droughts in different seasons (Van Loon, 2015). This is very relevant in the Anthropocene, because humans interact differently with droughts in different seasons. Water abstraction for irrigation, for example, also follows a sea- 


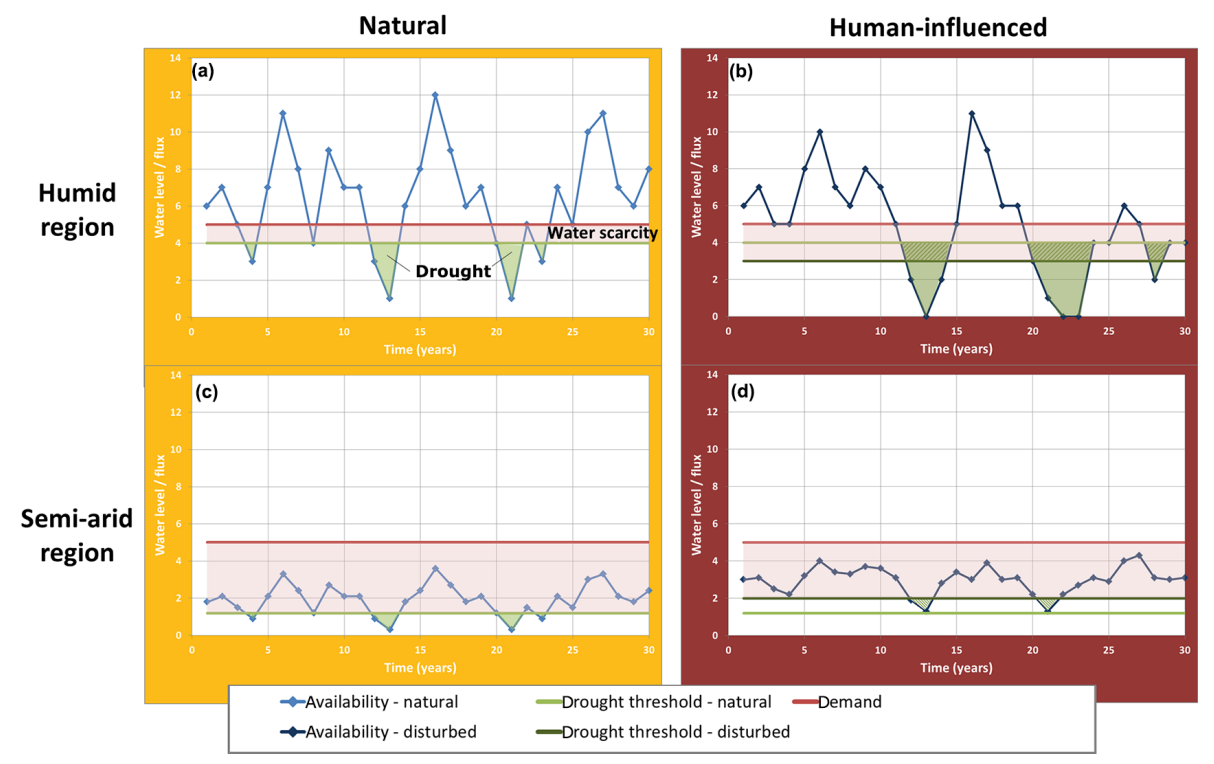

Figure 4. Conceptual figure of drought, aridity, and water scarcity. Average water availability (water levels or fluxes in rivers, lakes, reservoirs, or groundwater aquifers) are lower in arid climates (b) than in humid climates (a), resulting in a lower threshold under natural conditions. In both regions, climate-induced droughts are defined relative to this threshold (a and $\mathbf{b}$; green areas). The region experiences water scarcity when the long-term water demand is higher than the long-term water availability (a and $\mathbf{b}$; red areas). In human-influenced catchments (c and d), human-induced and human-modified droughts can be determined relative to a natural threshold (light green) or a human-influenced threshold (dark green), resulting in different drought events (green areas vs. dashed areas). For simplicity of this figure, we assumed a similar water demand in humid and arid climates and under natural and human-influenced conditions. Often, however, water demand is higher in arid climates and under human-influenced conditions leading to even more severe water scarcity and drought. NB: both the drought threshold and water demand can also be seasonally variable (e.g. Van Loon, 2015; Mekonnen and Hoekstra, 2016).

sonal pattern and has different effects on summer drought vs. winter drought. On the other hand, in monsoon climates, drought characterized by a prolonged dry season causes different socio-economic impacts than a below-normal wet season.

\subsection{Confusion between terms in the Anthropocene}

Drought is often confused with water scarcity and water shortage, which are defined as "less water than needed", i.e. where demand is greater than supply (Table 1). The demand, or desired level, is included in Fig. 4 to illustrate the difference. In an unpopulated natural region, the desired situation is related to ecosystem requirements. Often these are not different from the normal situation because of the coevolution of ecosystem and landscape. However, in a humandominated region, the desired situation or water demand is dependent on population, standard of living, water efficiency, but also on climate. In many areas, the desired situation is out of balance with the normal situation, i.e. average water demand is higher than average water availability, because of rapid population growth, changes in diet, etc. This long-term imbalance leads to water scarcity (see Rijsberman, 2006, for a good overview of water scarcity definitions) and when it coincides with short-term drought it leads to acute water shortage (Table 1 and Fig. 4). If society satisfies its demand by abstracting more water, human-induced drought can occur in the short term (changing the actual situation) and overexploitation in the long term (changing the normal situation; Table 1 and Fig. 4).

Human-induced drought should also not be confused with the term "socio-economic drought" (Wilhite and Glantz, 1985 , p. 115), which is used to denote socio-economic impacts of drought. Although socio-economic drought is often mentioned as a type of drought in scientific papers and on websites explaining drought to the general public, a clear distinction should be made between the physical lack of water (drought) and its socio-economic consequences (impacts of drought). These impacts are sometimes used to define the drought threshold (Fig. 3), which then reflects the water level at which ecological or socio-economic impacts are expected to occur, such as ecological minimum flow or minimum reservoir levels.

We have to point out that the definitions of drought and its impacts used here deviate from the definitions used in other scientific disciplines, in particular in the climate community. For example, in the IPCC SREX report, drought, as we define it here, is considered an "impact of extreme (weather or climate) on the natural physical environment" (IPCC, 2012, p. 40 and 167), whereas we see drought as a state of the natural physical environment that can cause ecological and socio- 
Table 1. Drought terminology in relation to drivers and timescales (based on Wilhite and Glantz, 1985; Tallaksen and Van Lanen, 2004; Rijsberman, 2006; Sheffield and Wood, 2011; Maliva and Missimer, 2012; Van Loon and Van Lanen, 2013; Lloyd-Hughes, 2014; Oertel et al., 2015; Stahl et al., 2016; Van Loon et al., 2016).

\begin{tabular}{ll}
\hline Term & Definition \\
\hline $\begin{array}{l}\text { Drought } \\
\text { Climate-induced drought }\end{array}$ & $\begin{array}{l}\text { Temporary lack of water compared to normal conditions } \\
\text { Drought caused by climate variability }\end{array}$ \\
$\begin{array}{l}\text { Human-induced drought } \\
\text { Human-modified drought }\end{array}$ & $\begin{array}{l}\text { Drought caused by human influence on water cycle } \\
\text { Drought caused by combination of climate variability and human influence on water cycle or } \\
\text { Climate-induced drought enhanced or alleviated by human activities }\end{array}$ \\
Drought impact & $\begin{array}{l}\text { Impact of drought on socio-economic systems (sometimes called "socio-economic drought") } \\
\text { and/or ecosystems }\end{array}$ \\
Aridity & $\begin{array}{l}\text { Long-term dryness as feature of climate, with long-term average precipitation being much lower than } \\
\text { potential evaporation }\end{array}$ \\
Water scarcity & $\begin{array}{l}\text { Long-term imbalance between water demand and water supply, caused by high average demand, low } \\
\text { average water availability and/or problems with water supply } \\
\text { Acute lack of water for (social, economic, or environmental) needs, caused by lower water } \\
\text { Supply than demand } \\
\text { Later shortage/stress }\end{array}$ \\
Overexploitation & (for overexploitation of groundwater, the term "depletion" is often used) \\
\hline
\end{tabular}

economic impacts. Similar confusion can arise for the terms "attribution", "mitigation", and "adaptation", which are often assumed to be synonymous with attribution, mitigation, and adaptation of (anthropogenic) climate change, but can also be used for the attribution, mitigation, and adaptation of drought.

\section{A framework for understanding and analysing drought in the Anthropocene}

The traditional view of drought propagation is unidirectional: climate variability causes drought, which propagates through the hydrological system and subsequently leads to impacts (Fig. 2, left side). Because of the complex relationships in the water cycle (Fig. 1) there are other drivers and modifications of drought and influences working in the opposite direction (Fig. 2). Therefore, the understanding of drought propagation needs to move from single driver to multiple drivers, and from uni-directional to bi-directional or even multi-directional.

For characterization of this complete multi-directional system, unfortunately, our understanding and observation of drought processes have important gaps and the modelling and prediction tools at our disposal are therefore inadequate. The gaps are in the areas of (1) drivers of drought, (2) modifications of drought, (3) impacts of drought, (4) feedbacks of drought, and (5) changing the normal situation. The framework presented in this section allows us to acknowledge what has been done in these areas, highlight where our understanding of drought processes in the Anthropocene is lacking, and discuss the data, approaches, and tools that are needed to address these gaps.

\subsection{Drivers of drought}

Drought is often seen from a meteorological perspective (Van Lanen et al., 2016), driven only by meteorological anomalies that disturb the normal water balance in a catchment (Fig. 2, left side). Given the significant human modifications of the terrestrial hydrological cycle, this is too simplistic a perspective (Box 1). If we take a hydrological perspective on drought, a lack of water compared to normal conditions can have a range of drivers (Fig. 2). There are many reasons for adopting a hydrological, rather than meteorological, perspective on drought. Firstly, people mainly use (sub)surface water, not rainfall directly (except for rainwater harvesting), so socio-economic impacts of drought are more related to a lack of (sub)surface water. Secondly, water on and beneath the land surface can be managed and manipulated, in contrast to rainfall, so that hydrological drought can be mitigated. Finally, the direct anthropogenic influences on hydrological drought are probably much larger than climate change influences in many areas of the world. If we adopt a hydrological perspective on drought, it is important to distinguish between the different drivers of drought. This distinction leads to more accurate drought prediction and helps to direct attention and allocate investments between adaptation to climate-induced drought and reduction of human-induced drought. However, distinguishing between climate-induced and human-induced drought is a major scientific challenge.

Human-induced droughts are recognized (Wilhite and Buchanan-Smith, 2005), but there is a large gap in our understanding of the development of human-induced and human-modified drought. We do know that human drivers principally influence soil moisture drought and hydrological drought and generally do not cause meteorological drought 
(Fig. 2; excluding relatively small-scale land surface feedback, e.g. due to irrigation (Tuinenburg et al., 2014), or the global, indirect effects of anthropogenic climate change). We can also hypothesize that the main process underlying human-induced and human-modified drought is abstraction from groundwater and surface water. There are many scientific studies on the long-term effects of abstraction (decades to centuries) but few on the temporal variability of abstraction on drought timescales (months to years). It is therefore still unclear how important human-induced and humanmodified droughts are compared to climate-induced droughts for different areas around the world.

Research questions about drought drivers include

- To what extent can observed historic drought events be attributed to different drivers?

- What are the dominant drivers of drought in different parts of the world?

- Do human-induced and human-modified droughts follow the same development as climate-induced drought and what are the implications for management?

Answering these questions requires quantification of the direct human drivers of soil moisture drought and hydrological drought, in absence of meteorological anomalies, for historical drought events. The approach would be to identify droughts in time series of observed hydrological variables and compare those to time series of climate-induced drought (represented by meteorological drought, observed droughts in an undisturbed nearby catchment, or simulated naturalized droughts). This last approach was used successfully in Australia (Van Dijk et al., 2013) and Spain (Van Loon and Van Lanen, 2013) and could be applied in other areas around the world to understand the variability in how human drivers impact drought. Naturalization of disturbed time series is challenging, being very much dependent on accurate modelling or regionalization approaches and data of human disturbances at a sufficiently high spatial and temporal resolution. Many international hydrological databases and data-sharing initiatives, however, have deliberately focused on near-natural systems (e.g. Hannah et al., 2011; Whitfield et al., 2012) in order to discern climate-driven processes from the noise of various human disturbances. We argue for more analysis of the disturbed catchments already included in hydrological databases and promote the extension of these databases with more human-influenced catchments, as suggested previously by Gustard et al. (2004). Perhaps the greatest obstacle to achieving this is the lack of metadata indexing the type and degree of human impact in any one catchment, which is often not known or poorly quantified. There is a pressing need for a bottom-up approach to transfer such knowledge, where it exists, from catchment-, regional- or national-scale archives to the international research community. We also call for more experimental catchments in human-influenced areas in which particular human influences on the hydrological cycle can be isolated and controlled, for example, within the Euromediterranean Network of Experimental and Representative Basins (ERB), the network of Critical Zone Observatories in the USA, and the TERestrial ENvironmental Observatories (TERENO) in Germany. Alternatively, we can make more use of satellite data of hydrological variables, which have become more widely available on the global scale, although still with high uncertainties (AghaKouchak et al., 2015b). Useful satellite products are soil moisture missions (SMAP, SMOS, AMSR-E II, ASCAT) for soil moisture information on high spatial and temporal resolution and NASA's Gravity Recovery and Climate Experiment (GRACE) for total water storage. If these are compared with global precipitation estimates (from satellites, TRMM and GPM, or from re-analysis), human-induced droughts might be identified in the absence of natural drought drivers.

\subsection{Modifications of drought}

The severity of droughts is strongly modified by catchment storage and release processes. In the natural situation these modifiers are determined by factors such as soil type, geology, and land cover (Fig. 2, left side). In the Anthropocene, human activities change storage and land properties influencing propagation processes, and modify drought severity directly through anthropogenic inflows or outflows of water (Fig. 2, right side). Just like natural modifiers, human modifiers can have both positive (enhancing) and negative (attenuating) effects on drought severity. The processes underlying direct modification of drought severity by human-influenced inflows or outflows of water are most recognized and understood, whereas the effects of human modification of storage and land properties, although recognized as potentially important, are more elusive.

There are ample examples of how human changes in land properties influence the hydrological cycle. Urbanization, for example, results in less infiltration and more runoff in some cases and in more recharge in others (due to leakage of water supply and sewage systems; Lerner, 1990). Deforestation, afforestation, agricultural practices, and desertification influence evapotranspiration and consequently soil moisture. Some studies focused on the effects of land use change on low flows (Tallaksen, 1993; Hurkmans et al., 2009), but there is very little quantitative research on how these processes influence drought severity and contrasting results are reported between modelling studies (Tallaksen, 1993; Hurkmans et al., 2009) and observation-based studies (Price et al., 2011; Eng et al., 2013).

Research questions about human modifications of drought include

- How do human modifications of drought enhance or alleviate drought severity? 
- How do we predict drought development, severity and recovery in human-influenced areas, taking into account relevant human drought modifiers?

Direct inflows or outflows of water are relatively easy to quantify with a water balance approach that explicitly takes into account human water flows (Lloyd-Hughes, 2014). However, this approach requires data of human influences on the water system, such as surface water and groundwater abstraction, inter-basin water transfers (Van Loon and Van Lanen, 2015), and irrigation return flows (De Graaf, et al., 2014). These data are usually not measured or collected, and if they are, there are often privacy issues in sharing the data, even for research. Additionally, there are many illegal or undocumented human influences on the water system that remain unknown (e.g. Pérez Blanco and Gómez, 2014). National statistical databases can be a good source of information, but their spatial resolution is often coarse, so downscaling might be needed. Examples of methods for downscaling information on water demand and water use can be found in Wada et al. (2011) and Nazemi and Wheater (2015a, b). More qualitative and local-scale information on the human influences in a catchment can be gathered by a range of methods, including interviews with local water users, participant diaries, oral recollections, community histories, participant observation, photographs and other visual materials, satellitederived land use maps, and novel methods such as unmanned aerial vehicles (also known as drones).

Besides new data, new methods are needed to disentangle human modifiers from natural modifiers of drought and quantify how large their effect on drought severity has been for historical drought events and might be for future events. When sufficient data are available, statistical methods, such as multiple regression analysis, can be useful in finding the statistical relationships between drought severity and multiple influencing factors. This approach was used by Van Loon and Laaha (2015) for natural drought modifiers, but can easily be extended to include human modifiers. Paired catchment statistical approaches (as applied to urbanization impacts on floods by Prosdocimi et al., 2015) or upstream (natural) - downstream (disturbed) comparisons (Fig. 5a; LópezMoreno et al., 2009; Rangecroft et al., 2016) are other datadriven approaches, although these have yet to be applied extensively for drought and low flows. Another large-scale data analysis method that has great potential for use in drought research is comparative analysis (Wagener et al., 2007), which aims to find patterns by analysing a large set of catchments with a wide range of characteristics, both in terms of natural and human processes (e.g. Price et al., 2011; Eng et al., 2013; Sadri et al., 2016). This method is especially valuable if it is combined with qualitative data to explain the patterns found.

For scenario testing, conceptual models of human-water systems (Di Baldassarre et al., 2013, 2015) are a useful tool. Natural flows are altered by the presence of reservoirs and the resulting outflows depend on (changing) operational rules,
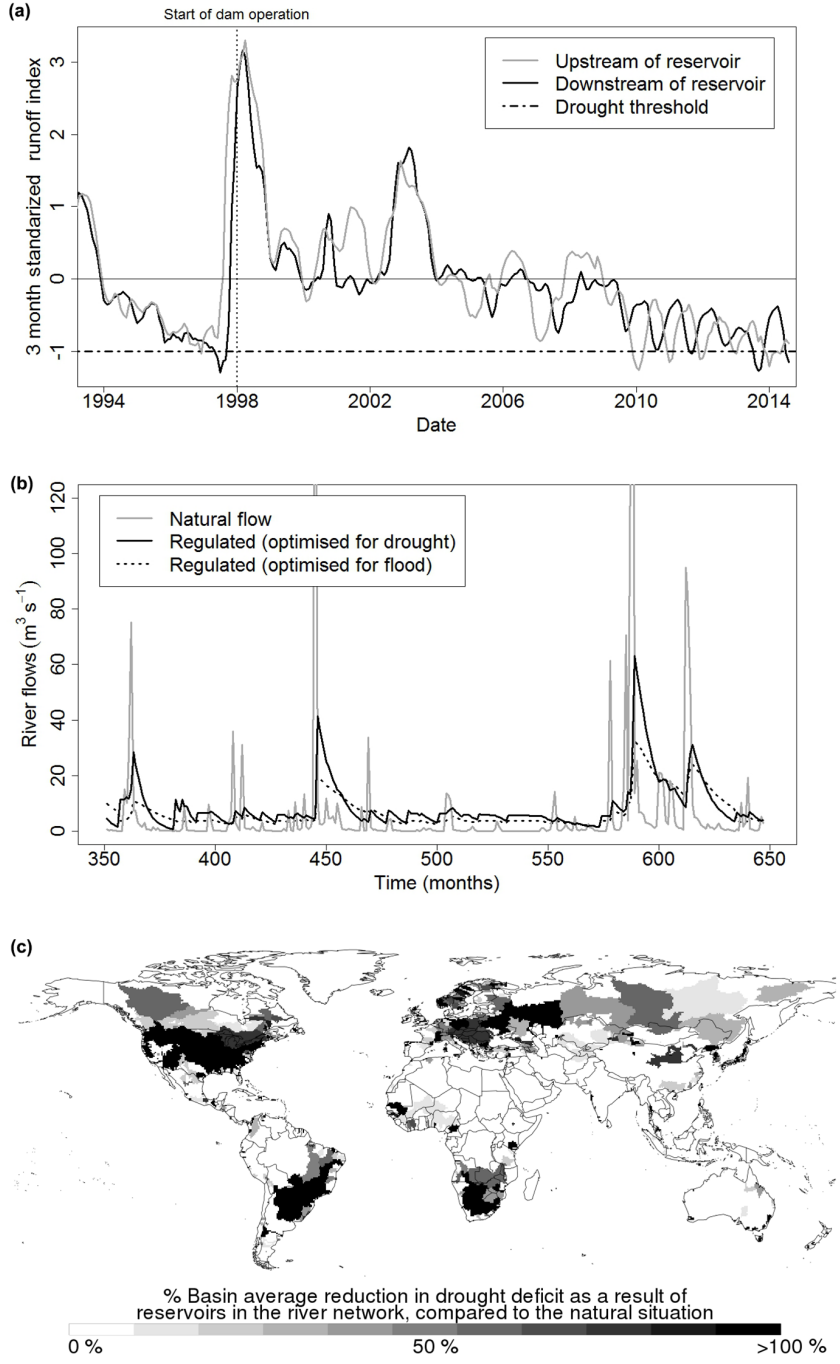

Figure 5. Example of the approaches to investigate drought modification by reservoirs, based on (a) observations of discharge upstream and downstream of a reservoir in Chile (Rangecroft et al., 2016), (b) theoretical effect of reservoirs on drought (Martinez et al., 2016), (c) simulated effect of reservoirs on drought deficit on global scale (adapted from Wanders and Wada, 2015).

i.e. optimized for flood or drought (Fig. 5b; e.g. Mateo et al., 2014). The conceptual model (Martinez et al., 2016) simulates how the occurrence of a flood event might lead to changes in operational rules (e.g. shifting from the "optimized for drought" to "optimized for flood" scenario in Fig. 5b), which will eventually enhance the next drought event (Di Baldassarre et al., 2016).

Modelling tools are also indispensable for prediction of drought under human modification. There are many types of models and many options to use these models for drought in the Anthropocene. Large-scale hydrological models are being adapted to include more anthropogenic processes (e.g. WaterGAP and PCR-GLOBWB; Wada et al., 2011; Döll 
et al., 2012; Nazemi and Wheater, 2015a; Veldkamp et al., 2015). Analysing these models specifically during drought periods has given some encouraging results (Fig. 5c; e.g. Van Lanen et al., 2004; Verbeiren et al., 2013; Wada et al., 2013; De Graaf, et al., 2014; Forzieri et al., 2014; Wanders and Wada, 2015), although model uncertainties during low flow and drought remain high. Since many human influences on the hydrological cycle are on the local scale, hyper-resolution modelling might be needed to explicitly represent all relevant human activities (Wood et al., 2011). For parameterization of these models, however, a thorough understanding of the processes is essential (Beven and Cloke, 2012). Most predictions on the local scale, however, are done with lumped or semi-distributed hydrological models. It is often not straightforward to incorporate dynamic human processes into these models and more work is needed to adapt these lumped hydrological models for use in the Anthropocene. An example of a new lumped hydrological model that incorporates man-made extraction and supply of water to both surface and subsurface water is WALRUS by Brauer et al. (2014). Current physically based models are better fitted to simulate human responses to drought, e.g. SIMGRO (Querner et al., 2008; Van Lanen et al., 2004). Once again, an important limiting factor is availability of data and metadata on the human modifiers. If information on human pressures is available, modelling can be a key tool in separating human and natural drivers (thus paving the way to attribution) through a multiple working hypotheses approach (see, for example, the work of Harrigan et al., 2014).

\subsection{Impacts of drought}

On the other side of the propagation diagram are the environmental and socio-economic impacts of drought (Fig. 2). Drought impacts, compared to the impacts of other hazards, are mostly non-structural and difficult to quantify. Drought impacts also have a high diversity, ranging across agriculture, water supply, industry, energy production, human health, aquatic ecology, forestry, and other sectors (Stahl et al., 2016). Impacts are sometimes characterized into direct and indirect or tangible and intangible impacts (Wilhite and Vanyarko, 2000). Thus, the quantification of drought impacts depends on the affected sector and on the level of impact (direct or indirect, and perhaps cumulative). Direct impacts on the agricultural sector are often documented as losses or reductions in crop yields. However, associating indirect economic losses directly to drought is not always straightforward (Ding et al., 2011). Indirect negative consequences are often quantified by the number of people affected or by number of people who died as a result of related food security or health issues, but factors other than a direct association to drought may play an important role as well. Especially drought impacts on (mental) health are complex and dependent on a multitude of factors (Stanke et al., 2013; Obrien et al., 2014).
Whether a drought event has negative consequences on one of these sectors also depends strongly on people's perception and thus on the vulnerability of affected sectors (Knutson et al., 1998; Iglesias et al., 2009). Understanding a particular sector's vulnerability can benefit from specific information and quantification of drought impacts in addition to knowledge on the general vulnerability factors that describe the sensitivity and adaptive capacity of the considered community or region.

For drought characteristics, ample data sources exist. However, as noted before, they rarely specify the level of human modification to the drought signal.

Research questions that need to be addressed thus include

- How should drought impacts be monitored and quantified?

- How do they depend on the physical characteristics of drought vs. the vulnerability of people or the environment?

For drought impacts, the US Drought Impact Reporter (DIR) (http://droughtreporter.unl.edu/) and the European Drought Impact report Inventory (EDII) in Europe (http://www.geo. uio.no/edc/droughtdb/) collect and categorize textual drought impact reports, whereas Lackstrom et al. (2013) and others suggest the development of a more targeted impact monitoring. A survey of operational monitoring and early warning systems by Bachmair et al. (2016a) found that many regional systems do monitor impacts, however, not in a systematic way and thus they do not consider them for the drought warning and other management in a quantitative manner. Hence, impact monitoring is an important starting point for improvement. For vulnerability analysis, likewise many useful data on the sensitivity or adaptive capacity from community to country to international levels are lacking (De Stefano et al., 2015). Where data are available, however, research can target to find a useful and applicable functional link between these aspects of drought.

Retrospective analysis of the physical characteristics of past droughts (through some drought indicator) and the impacts that they have triggered have moved this search for a link function forward, especially if compared across different societal contexts, in particular different degrees of vulnerability. However, methods to link physical indicators and societal impacts have only recently been explored more in depth and still require more systematic appraisal. Figure 6 gives an overview of the different methods. The most widely adopted approach to relate drought indicators to impacts is to link commonly used hydrometeorological drought indicators to agricultural yield (Lobell et al., 2008; Vicente-Serrano et al., 2012, 2013; Bachmair et al., 2016a). Most of these studies are based on correlation and as summarized by Stagge et al. (2015a), thus are useful for screening relationships, but they measure the response of a variable, such as crop yield, across its entire range of values including typical or 


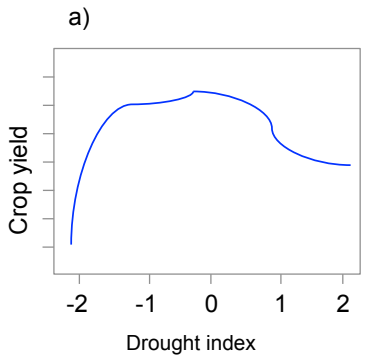

b)

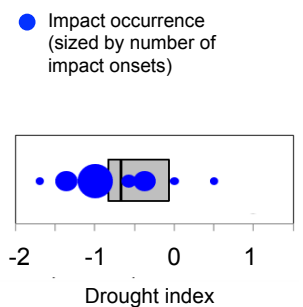

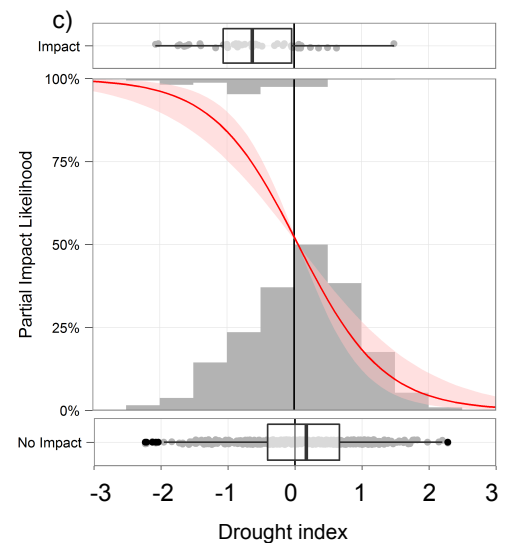

Figure 6. Scheme of the three approaches to investigate impact-related drought index values: (a) correlation of drought index to crop yield (from unpublished work), (b) drought index values at the time of impact occurrence (based on Bachmair et al., 2015), and (c) logistic regression model predicting the likelihood of impact occurrence by the drought index (as in Stagge et al. (2015), but for drought index SPI instead of SPEI).

even productive years. A further complicating factor is the non-linearity of the climate-yield relation, which can show ambiguous relations with positive effects during drought or threshold behaviour for reductions in yield (Fig. 6a). Reportbased impact data cover a wider range of impact types, but are tedious to gather and have many biases. So far, they have mostly been converted to binary or counts of "impact occurrences" for indicator-to-impact studies (Fig. 6b). Data-driven statistical models have used time series or spatial variability of these impact occurrences as a response variable in regression and classification tree models (Fig. 6c; Stagge et al., 2015a; Bachmair et al., 2016b; Blauhut et al., 2015). These studies have also shown that impact generation is more complex than previously assumed and may be caused by the cooccurrence of several extremes, lagged effects, and seasonality (Stagge et al., 2015a). A useful outcome of these modelling exercises was the objective determination of "bestindicators" for impacts in particular sectors that are strongly influenced by human factors. For example, when using the Standardized Precipitation Index (SPI) or Standardized Precipitation Evapotranspiration Index (SPEI) the best accumulation period suited to predict agricultural impacts clearly differs for irrigated and rain-fed agriculture (Stagge et al., 2015a); similarly, the best accumulation period to predict drought impact on public water supply differs depending on the relative contributions of groundwater vs. surface water resources and the type of reservoirs available (Bachmair et al., 2016b). These examples show that human perception of drought impacts can differ from the occurrence of drought in the natural hydrological system, depending on the prevailing water management framework and thus the vulnerability. Future analysis could use impact information to better characterize impacts of human-modified or human-induced drought.

\subsection{Human feedback of drought}

The interaction between natural hydroclimatological processes and human influences is not a simple addition of both effects, but instead comprises complex and dynamic feedbacks resulting in a strongly non-linear response of the hydrological system (Fig. 2). There are negative feedbacks, when human management responses to drought (impacts) lessen drought; and positive feedbacks, where management responses exacerbate drought. There is growing knowledge of climate feedbacks (also called land-atmosphere feedback), in which drought influences evapotranspiration rates positively or negatively (Teuling et al., 2013), dependent on geographic situation and time frame. There is, however, only very limited understanding of human feedbacks during drought.

Short-term human feedbacks are responses to drought situations (whether observed, or at least perceived, or predicted) that influence water storages and fluxes within a particular water system in a catchment over timescales of days to years. These influences can include reductions in water use, implementation of water-saving technologies, planting of less water-demanding crops, using other water sources (e.g. from surface water to groundwater; from clean to grey water), short-term increases in groundwater abstraction because of surface water shortage, and water transfer from wetter areas or areas where water demand is lower (e.g. Andreu et al., 2005).

There is strong non-linearity in the reaction of the water system to these short-term influences (Sivapalan et al., 2012). Timescales often do not match; for example, the societal response might be in the order of weeks, but the reaction of groundwater can be in the order of years (Gleeson et al., 2010; Castle et al., 2014). Consequently, there is a difference between short- and long-term droughts, where longer 
droughts show a more complex interaction of natural and human processes (Van Dijk et al., 2013). Societies can also learn from historic droughts and adapt drought policy in the long-term to be more proactive, rather than reactive, when the next drought comes (McLeman et al., 2014). Crucially, however, human activities are not only influenced by climate and the drought state of the system but are also strongly dependent on domestic water behaviours (Pullinger et al., 2013), national policy styles (Gober, 2013), existing public policies (particularly for agriculture; Campos, 2015), water law and governance (Maggioni, 2015), and even indirectly by international food markets and geopolitics.

Research questions about human feedbacks include

- Are there commonalities in the response of different societies to different drought events?

- To what extent are physical and human drought processes coupled, and can feedback loops be identified and altered to lessen or mitigate drought?

- What are the links between discourses and practices of drought mitigation and alleviation?

Additionally, more information is needed on past histories of water use and the role of technology in current routines of water practice (Pullinger et al., 2013), tipping points in human water use (Mera et al., 2014), and the reasons for a lack of public awareness of environmental water demands (Dessai and Sims, 2010). Understanding the relationship between these factors is crucial to enhancing our understanding of drought.

Qualitative data are essential in our quest for increased understanding of this topic. One novel type of qualitative data is the use of drought narratives (i.e. stories of historic drought events), which can give new insights into societal responses and feedbacks (e.g. Daniels and Endfield, 2009). This is an example of how citizen science can help harvest data. It is especially interesting to study paired drought events, i.e. drought events of similar magnitude that occurred in the same region, to investigate whether societies learn from drought events and what the effect of this learning is on the next drought. Despite the obvious uncertainties of such an approach, it can provide information on drought responses and feedbacks from one drought event to the next, as was shown for paired flood events by Kreibich et al. (2016).

For quantitative prediction of the effect of feedback on drought, water management models could be adapted to include more hydrology and feedbacks. The modelling tools that are used in water management generally take water availability as external forcing and do not include the feedbacks of the water use on the hydrological system (e.g. Higgins et al., 2008; Borgomeo et al., 2014). Like some global and lumped hydrological models mentioned before, many water management models are capable of simulating the effect of the allocation of water on hydrological processes also during drought, as was shown by Querner et al. (2008) and Van Oel et al. (2012), or simulating the influence of water management decisions on the evolution of a given drought scenario (e.g. Watts et al., 2012).

Socio-hydrology models aim to account explicitly for the two-way feedbacks between social and hydrological processes (e.g. Sivapalan et al., 2012). Di Baldasarre et al. (2013, 2015) have applied this approach to flooding, and the development of a similar modelling framework for drought is underway (Kuil et al., 2015). As the interplay between water and people is still poorly understood, socio-hydrological theory is still to be developed via an iterative process of empirical study, comparative analysis, and process-based modelling. Thus, while the current studies do contribute to improve the current understudying of water-society interactions, their predictive power is still very limited (Viglione et al., 2014). Modelling approaches are most successful when people themselves are actively involved in the modelling process; stakeholders can, for example, guide scenario analysis (Loucks, 2015). In contrast to modelling studies, environmental social science epistemologies, such as grounded theory building, offer alternative means of understanding water resource use and human behaviour (Pearce et al., 2013), potentially enabling more holistic insights into the role of drought feedbacks in the hydrosocial cycle (Linton and Budds, 2014, p. 170).

\subsection{Changing the normal situation}

We now live in a fast-changing environment; both climate change and long-term human influences on the water cycle are changing the reference normal situation, even within 30year time blocks that are traditionally being used to determine a climatology or a drought threshold. This is important from a drought perspective because the normal situation is our reference to determine the occurrence and severity of drought events (Fig. 4). There are many uncertainties in dealing with extreme events like drought under conditions of change. Some model studies of future hydrological drought commented on the assumption of using the same threshold for the historic and the future period (e.g. Giuntoli et al., 2015; Wanders et al., 2015). Two aspects should be mentioned. Firstly, regime changes trigger methodological considerations, because they can result in detection of drought events that should otherwise not be classified as drought, such as earlier snowmelt resulting in a drought in the normal snowmelt period (Lehner et al., 2006; Van Huijgevoort et al., 2014). Secondly, ecological and societal systems might adapt to a changing normal situation, but it is unclear how fast these adaptations will take place and whether tipping points will be passed (Mera et al., 2014).

Research questions related to a changing normal situation include 


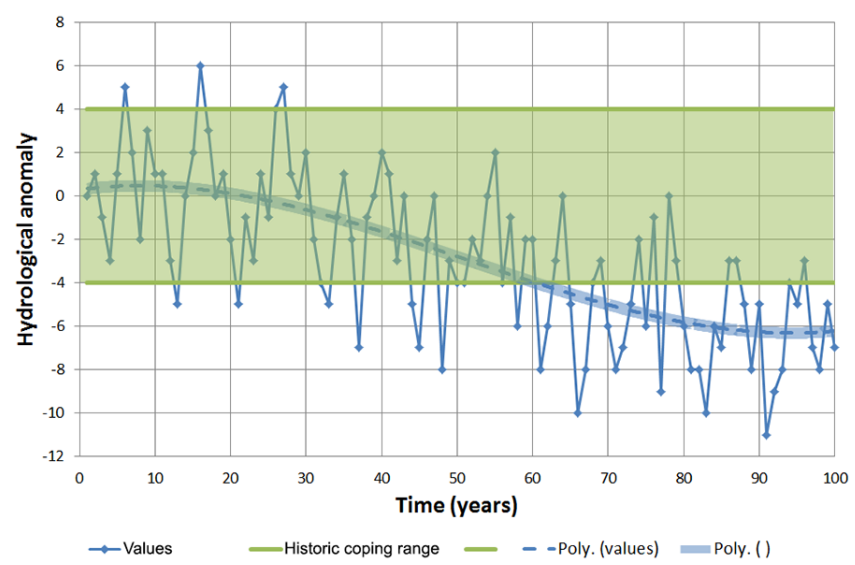

Figure 7. A changing normal situation due to climate change changes drought occurrence and severity (after Smit et al., 2000). Will society adapt to changing normal situation or in response to one/two extreme events?

- Is the normal situation actually changing or do we not have the data or understanding of natural variability to say anything about what is normal?

- How do long-term human influences on the water cycle change the normal situation?

- Do societies adapt to changes in the normal situation so that more severe droughts might lead to less impact in the future?

- How should we adapt our drought analysis to accommodate changes in the normal situation?

The most straightforward solution to regime shifts is analysing different seasons separately, as was done by Hisdal et al. (2001) and Feyen and Dankers (2009) with respect to a snow season and non-snow season. In historical drought analyses, long-term climate change effects are often excluded by taking a short-enough period to neglect climate change or by detrending the time series. For a changing normal situation, due to future climate change, Vidal et al. (2012) and Wanders et al. (2015) have suggested to include adaptation by changing the drought threshold for the future. Mondal and Mujumdar (2015) followed a similar approach by estimating changes in return levels of drought under similar probability of occurrence in observed and projected streamflow. These methodologies should be evaluated more thoroughly and should also be applied to account for long-term human influences, alongside climate change effects. Important long-term human influences to consider are anthropogenic land use change (urbanization and deforestation; Verbeiren et al., 2016), continuous increases in abstraction, and step changes in storage by dam building (e.g. Wisser et al., 2010; Pokhrel et al., 2012).

These methodological explorations on how to deal with changes of the normal situation in drought analysis are ur- gently needed, but we should also get a better understanding of long-term changes in the perception of drought impacts and vulnerability. This perception drives adaptation to extreme events like drought and influences feedbacks between the physical and social system. Societies might be able to adapt to a changing mean, but they are more likely to be triggered by extreme impacts of a severe drought, resulting in long-term adaptations aiming to reduce impacts of drought in the future (Fig. 7; Smit et al., 2000; Dillehay and Kolata, 2004). More research is needed to understand trajectories of social development that lead to adaptation to drought.

We can benefit from the work done on long timescales, regarding long-term climate change, long-term human influence on the water cycle (overexploitation), and long-term water demand and scarcity (Table 1). Research on groundwater depletion (Aeschbach-Hertig and Gleeson, 2012) and water scarcity (Rijsberman, 2006) has been carried out on large temporal and spatial scales (annual and country level), because that is the level of relevance and the level of available data. Accounting for temporal variability and increasing spatial resolution can close the gap with drought research (Savenije, 2000; Hoekstra et al., 2012; Hering et al., 2015; Vörösmarty et al., 2015). Veldkamp et al. (2015) and Mekonnen and Hoekstra (2016) were the first to explore sub-annual timescales of water scarcity.

\section{A broader scope on drought in the Anthropocene}

The framework proposed here is in line with suggestions for hydrological research in general, for example, with the call by Wagener et al. (2010) for a paradigm shift to study hydrology under change, with the research agenda set by Thompson et al. (2013) for hydrological prediction in the Anthropocene, with the new decade of the International Association of Hydrological Sciences (IAHS) Panta Rhei (Montanari et al., 2013; McMillan et al., 2016), and with the propositions for hydrological research and water management by Vogel et al. (2015). Complementary to these visions on the future of hydrology in general, we think that a focus on drought is needed to cope with complex future water challenges.

The challenges mentioned here are, however, not unique to drought. We can learn from other fields that have struggled or are still struggling with similar issues. The parallels with flood research have already been mentioned above in relation to definitions and socio-hydrology. Flood research is further advanced than drought research in including human influences on catchments and rivers in flood analysis (e.g. Vorogushyn and Merz, 2013) and many studies exist that focus on attribution of flood to different drivers and modifications, the complex interaction between natural and human processes, and flood response and adaptation.

There is also an interesting parallel between society and ecology, because, just like people, plants are simultaneously dependent on and shape water availability (e.g. Rodriguez- 
Iturbe, 2001). The field of ecohydrology has evolved in the last 15 years to a quantitative understanding of the interrelated dynamics of plants and water (e.g. Hannah et al., 2007; Asbjornsen et al., 2011; Jenerette et al., 2012). The importance of including vegetation feedback in future drought modelling was, for example, highlighted by Prudhomme et al. (2014). Similar approaches can be applied to the interrelated dynamics of people and water, especially during drought. In addition, the field of hydroecology has been grappling for several decades with the same issue of how to capture reference natural conditions in order to compare impacted conditions against them. Again, this is hampered because there are so few extant examples of natural conditions in observed hydrological data sets; the same challenges of how to naturalize flows have been at the core of the environmental flow paradigm (e.g. Acreman and Dunbar, 2004).

Societies have always had to cope with drought, so water management and governance have a long history. Especially interesting are the stories of civilizations that collapsed due to a combination of water overexploitation, drought, and other factors (e.g. Lucero, 2002). But there are many examples of successful water management in the past that have reduced drought severity or led to successful adaptation (e.g. Dillehay and Kolata, 2004; Garnier, 2015), which can help to understand feedbacks between society and the water system. In this light, it is also very informative to understand how people deal with uncertainties in drought prediction (Kasprzyk et al., 2009; Wagener et al., 2010), which are partly caused by the gaps in our understanding and unsuitability of data and tools to quantify the interaction between people and drought in the Anthropocene (Vogel et al., 2015). The use of drought predictions by society plays an important role in the impacts and feedbacks of drought. For improved drought management in the Anthropocene, a better two-way communication between scientists, stakeholders, policy makers, and the general public is needed. There are often social, psychological, and organizational barriers that prevent optimal use of scientific understanding in decision making. They are not our primary focus here, but clearly they can play an important role.

Although water scarcity is very different from drought, and water demand is not the focus of this article, regions with high water demand often influence the water cycle more drastically, possibly resulting in more human-induced drought and human-modified drought compared to regions with low water demand. Additionally, high-demand regions will be more severely impacted by drought than low-demand regions. Since increases in global water demand are projected for the future, enhancing water scarcity, collaboration between drought research and water scarcity research is urgently needed.

In focussing on human aspects of drought, we should not forget the other parts of the complex interlinked system (Fig. 1). Ecological and environmental requirements are recognized but are often neglected during drought (Vörös- marty et al., 2010). For example, in the Murray-Darling Basin (Australia) water management mitigated the water supply and economic impacts of drought, but at the same time strongly amplified the negative environmental impacts of drought (Van Dijk et al., 2008). Deterioration of water quality during drought can mean that water is available but cannot be used, for example, due to algal blooms or salt water intrusion in deltas (Van Vliet and Zwolsman, 2008). Although water quality was not discussed in this article, we stress that there are many challenges related to water quality and drought in the Anthropocene that require further research (e.g. Mosely, 2015).

In this article, we have argued that drought in the Anthropocene is not an external natural hazard. Instead, the natural hazard is intertwined with human influences on the water cycle and feedbacks of society on drought. We, therefore, explicitly include human processes in drought definitions and clarify previous confusion with related terms such as water scarcity. We present a multi-driver and multi-directional drought framework, in which human drivers, modifications, impacts, feedbacks, and changing the normal situation of drought are included in drought research. This framework highlights gaps in our understanding and indicates the tools and data needed. The elements of the framework have increasing complexity, from relatively straightforward aspects, like human drivers and modifications of drought, to the more complex impacts of drought, to compound feedbacks and changing the normal situation that integrate across all other elements.

The framework can be used to focus on a specific point or research question with the aim to solve part of the puzzle, or to study the entire interrelated system with the aim to put the pieces of the puzzle together. In the end, both approaches will hopefully result in a more holistic view of drought in the Anthropocene and consequently better drought management, in which the appropriate understanding and data and tools are used to take effective measures to mitigate drought severity, and to reduce drought impacts in the Anthropocene (Van Loon et al., 2016). This is of crucial importance now that the world is facing increasing human influence on the hydrological system, increasing dependence of society on water availability, combined with significant population growth and climate change, possibly leading to an increasing frequency of extreme hydroclimatological events (Vörösmarty et al., 2000; Oki and Kanae, 2006).

Author contributions. Anne F. Van Loon initialized the ideas presented in this paper with Henny A. J. Van Lanen, Tom Gleeson, Remko Uijlenhoet, and Adriaan J. Teuling. All authors contributed to the discussions that shaped the paper. Anne F. Van Loon prepared the manuscript with parts written by Julian Clark and Kerstin Stahl, and contributions from all co-authors. Figures were prepared by Anne F. Van Loon, Sally Rangecroft, Giuliano Di Baldassarre, Niko Wanders, Kerstin Stahl, Boud Verbeiren, and Tom Gleeson. 
Acknowledgements. The present work was (partially) developed within the framework of the Panta Rhei Research Initiative of the International Association of Hydrological Sciences (IAHS). It draws from discussion in (amongst others) the EU FP7 Project DROUGHT-R\&SPI (282769), supports the work of the UNESCOIHP VIII FRIEND-Water programme, and is partly funded by the Dutch NWO Rubicon project "Adding the human dimension to drought" (reference number: 2004/08338/ALW). We want to thank the editor Hilary McMillan, two anonymous reviewers, and Marc Bierkens for their constructive comments on our paper.

Edited by: H. McMillan

Reviewed by: two anonymous referees

\section{References}

Acreman, M. C. and Dunbar, M. J.: Defining environmental river flow requirements - a review, Hydrol. Earth Syst. Sci., 8, 861876, doi:10.5194/hess-8-861-2004, 2004.

Aeschbach-Hertig, W. and Gleeson, T.: Regional strategies for the accelerating global problem of groundwater depletion, Nature Geosci., 5, 853-861, doi:10.1038/ngeo1617, 2012.

AghaKouchak, A., Feldman, D., Hoerling, M., Huxman, T., and Lund, J.: Water and climate: Recognize anthropogenic drought, Nature, 524, 409-411, doi:10.1038/524409a, 2015a.

AghaKouchak, A., Farahmand, A., Melton, F. S., Teixeira, J., Anderson, M. C., Wardlow, B. D., and Hain, C. R.: Remote sensing of drought: Progress, challenges and opportunities, Rev. Geophys., 53, 452-480, 2015 b.

Andreu, J., Rossi, G., Vagliasindi, F., and Vela, A. (Eds.): Drought Management and Planning for Water Resource, CRC Taylor \& Francis, Boca Raton, USA, 255 pp., 2005.

Andreu, J., Ferrer-Polo, J., Pérez, M. A., and Solera, A.: Decision support system for drought planning and management in the Jucar river basin, Spain, in: 18th World IMACS/MODSIM Congress, Cairns, Australia, 13-17, 2009.

Asbjornsen, H., Goldsmith, G. R., Alvarado-Barrientos, M. S., Rebel, K., Van Osch, F. P., Rietkerk, M., and Dawson, T. E.: Ecohydrological advances and applications in plant-water relations research: a review, J. Plant Ecol., 4, 3-22, 2011.

Bachmair, S., Kohn, I., and Stahl, K.: Exploring the link between drought indicators and impacts, Nat. Hazards Earth Syst. Sci., 15, 1381-1397, doi:10.5194/nhess-15-1381-2015, 2015.

Bachmair, S., Stahl, K., Collins, K., Hannaford, J., Acreman, M., Svoboda, M., Knutson, C., Smith, K. H., Wall, N., Fuchs, B., Crossman, N. D., and Overton, I. C.: Drought indicators revisited: the need for a wider consideration of environment and society, WIREs Water, doi:10.1002/wat2.1154, 2016a.

Bachmair, S., Svensson, C., Hannaford, J., Barker, L. J., and Stahl, K.: A quantitative analysis to objectively appraise drought indicators and model drought impacts, Hydrol. Earth Syst. Sci., 20, 2589-2609, doi:10.5194/hess-20-2589-2016, 2016b.

Beven, K. J. and Cloke, H. L.: Comment on "Hyperresolution global land surface modeling: Meeting a grand challenge for monitoring Earth's terrestrial water" by Eric F. Wood et al., Water Resour. Res., 48, W01801, doi:10.1029/2011WR010982, 2012.

Blauhut V., Gudmundsson, L., and Stahl, K.: Towards panEuropean drought risk maps: quantifying the link between drought indices and reported drought impacts, Environ. Res. Lett., 10, 014008, doi:10.1088/1748-9326/10/1/014008, 2015.

Bloomfield, J. P. and Marchant, B. P.: Analysis of groundwater drought building on the standardised precipitation index approach, Hydrol. Earth Syst. Sci., 17, 4769-4787, doi:10.5194/hess-17-4769-2013, 2013.

Borgomeo, E., Hall, J. W., Fung, F., Watts, G., Colquhoun, K., and Lambert, C.: Risk-based water resources planning: Incorporating probabilistic nonstationary climate uncertainties, Water Resour. Res., 50, 6850-6873, 2014.

Brauer, C. C., Teuling, A. J., Torfs, P. J. J. F., and Uijlenhoet, R.: The Wageningen Lowland Runoff Simulator (WALRUS): a lumped rainfall-runoff model for catchments with shallow groundwater, Geosci. Model Dev., 7, 2313-2332, doi:10.5194/gmd-7-23132014, 2014.

Campos, J.: Paradigms and public policies on drought in northeast Brazil: A historical perspective, Environ. Manage., 55, 10521063, 2015.

Castle, S. L., Thomas, B. F., Reager, J. T., Rodell, M., Swenson, S. C., and Famiglietti, J. S.: Groundwater depletion during drought threatens future water security of the Colorado River Basin, Geophys. Res. Lett., 41, 5904-5911, doi:10.1002/2014GL061055, 2014.

Ciais, P., Reichstein, M., Viovy, N., Granier, A., Ogée, J., Allard, V., and Valentini, R.: Europe-wide reduction in primary productivity caused by the heat and drought in 2003, Nature, 437, 529-533, 2005.

Crutzen, P. J.: Geology of mankind, Nature, 415, p. 23, doi:10.1038/415023a, 2002.

Daniels, S. and Endfield, G. H.: Narratives of climate change: introduction, J. Hist. Geograph., 35, 215-222, 2009.

De Graaf, I. E. M., van Beek, L. P. H., Wada, Y., and Bierkens, M. F. P. Dynamic attribution of global water demand to surface water and groundwater resources: effects of abstractions and return flows on river discharges, Adv. Water Resour., 64, 21-33, 2014.

De Kraker, A. M. J.: Flooding in river mouths: human caused or natural events? Five centuries of flooding events in the SW Netherlands, 1500-2000, Hydrol. Earth Syst. Sci., 19, 26732684, doi:10.5194/hess-19-2673-2015, 2015.

Dessai, S. and Sims, C.: Public perception of drought and climate change in southeast England, Environ. Hazards, 9, 340$357,2010$.

De Stefano, S. D., Gudmundsson, L., Gunst, L., Kohn, I., Van Lanen, H. A., Reguera, J. U., and Tallaksen, L. M.: Recommendations for indicators for monitoring and early-warning considering different sensitivities: pan-European scale. DROUGHT-R\&SPI Technical Report No. 26, 121 pp., available at: http://www.eudrought.org/technicalreports/ (last access: 18 May 2016), 2012.

Di Baldassarre, G., Viglione, A., Carr, G., Kuil, L., Salinas, J. L., and Blöschl, G.: Socio-hydrology: conceptualising humanflood interactions, Hydrol. Earth Syst. Sci., 17, 3295-3303, doi:10.5194/hess-17-3295-2013, 2013.

Di Baldassarre, G., Viglione, A., Carr, G., Kuil, L., Yan, K., Brandimarte, L., and Blöschl, G.: Debates - Perspectives on socio-hydrology: Capturing feedbacks between physical and social processes, Water Resour. Res., 51, 4770-4781, doi:10.1002/2014WR016416, 2015. 
Di Baldassarre, G., Martinez, F., Zalantari, Z., and Viglione, A.: Modelling Floods and Droughts in the Anthropocene, submitted, 2016.

Diffenbaugh, N. S., Swain, D. L., and Touma, D.: Anthropogenic warming has increased drought risk in California, P. Natl. Acad. Sci., 112, 3931-3936, 2015.

Dillehay, T. D. and Kolata, A. L.: Long-term human response to uncertain environmental conditions in the Andes, P. Natl. Acad. Sci., 101, 4325-4330, 2004.

Ding, Y., Hayes, M. J., and Wildham, M.: Measuring economic impacts of drought: a review and discussion, Disaster Prev. Manage., 20, 434-446, doi:10.1108/09653561111161752, 2011.

Döll, P., Hoffmann-Dobrev, H., Portmann, F. T., Siebert, S., Eicker, A., Rodell, M., and Scanlon, B. R.: Impact of water withdrawals from groundwater and surface water on continental water storage variations, J. Geodynam., 59, 143-156, 2012.

Eng, K., Wolock, D. M., and Carlisle, D. M.: River flow changes related to land and water management practices across the conterminous United States, Sci. Total Environ., 463, 414-422, 2013.

Falkenmark, M. and Rockström, J.: Building resilience to drought in desertification-prone savannas in Sub-Saharan Africa: The water perspective, in: Natural Resources Forum, 32, 93-102, Blackwell Publishing Ltd., 2008.

Feyen, L. and Dankers, R.: Impact of global warming on streamflow drought in Europe, J. Geophys. Res., 114, D17116, doi:10.1029/2008JD011438, 2009.

Fleig, K., Tallaksen, L. M., Hisdal, H., Stahl, K., and Hannah, D. M.: Inter-comparison of weather and circulation type classifications for hydrological drought development, Phys. Chem. Earth, 35, 507-515, doi:10.1016/j.pce.2009.11.005, 2010.

Forzieri, G., Feyen, L., Rojas, R., Flörke, M., Wimmer, F., and Bianchi, A.: Ensemble projections of future streamflow droughts in Europe, Hydrol. Earth Syst. Sci., 18, 85-108, doi:10.5194/hess-18-85-2014, 2014

Foster, T., Brozović, N., and Butler, A. P.: Why well yield matters for managing agricultural drought risk, Weather Clim. Extremes, 10, 11-19, 2015.

Garnier, E.: A historic experience for a strenthened resilience. European societies in front of hydro-meteors 16th-20th centuries', in: Prevention of hydrometeorological extreme events-Interfacing sciences and policies, edited by: Quevauviller, P., Wiley Publisher, New York, 1, 3-26, 2015.

Giuntoli, I., Vidal, J.-P., Prudhomme, C., and Hannah, D. M.: Future hydrological extremes: the uncertainty from multiple global climate and global hydrological models, Earth Syst. Dynam., 6, 267-285, doi:10.5194/esd-6-267-2015, 2015.

Gleeson, T., VanderSteen, J., Sophocleous, M. A., Taniguchi, M., Alley, W. M., Allen, D. M., and Zhou, Y.: Groundwater sustainability strategies, Nature Geosci., 3, 378-379, 2010.

Gober, P.: Getting Outside the Water Box: The Need for New Approaches to Water Planning and Policy, Water Resour Manage., 27, 955-957, 2013.

Grayson, M.: Agriculture and drought, Nature, 501, S1, doi:10.1038/501S1a, 2013.

Gudmundsson, L., Rego, F. C., Rocha, M., and Seneviratne, S. I.: Predicting above normal wildfire activity in southern Europe as a function of meteorological drought, Environ. Res. Lett., 9, 084008, doi:10.1088/1748-9326/9/8/084008, 2014.
Güneralp, B., Güneralp, İ., and Liu, Y.: Changing global patterns of urban exposure to flood and drought hazards, Global Environ. Change, 31, 217-225, 2015.

Gustard, A., van Lanen, H. A. J. and Tallaksen, L. M.: Outlook, Chapter 12, in: Hydrological Drought, Processes and Estimation Methods for Streamflow and Groundwater, Developments in Water Science, edited by: Tallaksen, L. M., and van Lanen, H. A. J., 48, Elsevier Science B.V., 485-498, 2004.

Hamilton, C.: Define the Anthropocene in terms of the whole Earth, Nature, 536, p. 251, doi:10.1038/536251a, 2016.

Hannah, D. M., Demuth, S., van Lanen, H. A., Looser, U., Prudhomme, C., Rees, G., and Tallaksen, L. M.: Large-scale river flow archives: importance, current status and future needs, Hydrol. Process., 25, 1191-1200, 2011.

Hannah, D. M., Sadler, J. P., and Wood, P. J.: Hydroecology and ecohydrology: a potential route forward?, Hydrol. Process., 21, 3385-3390, 2007.

Harrigan, S., Murphy, C., Hall, J., Wilby, R. L., and Sweeney, J.: Attribution of detected changes in streamflow using multiple working hypotheses, Hydrol. Earth Syst. Sci., 18, 1935-1952, doi:10.5194/hess-18-1935-2014, 2014.

Hering, J. G., Sedlak, D. L., Tortajada, C., Biswas, A. K., Niwagaba, C., and Breu, T.: Local perspectives on water. Science, 349, 479480, 2015.

Higgins, A., Archer, A., and Hajkowicz, S.: A stochastic non-linear programming model for a multi-period water resource allocation with multiple objectives, Water Resour. Manage., 22, 14451460, 2008.

Hisdal, H., Stahl, K., Tallaksen, L. M., and Demuth, S.: Have streamflow droughts in Europe become more severe or frequent?, Int. J. Climatol., 21, 317-333, 2001.

Hoekstra, A. Y., Mekonnen, M. M., Chapagain, A. K., Mathews, R. E., and Richter, B. D.: Global Monthly Water Scarcity: Blue Water Footprints versus Blue Water Availability. PLoS ONE, 7 e32688, doi:10.1371/journal.pone.0032688, 2012.

Hurkmans, R. T. W. L., Terink, W., Uijlenhoet, R., Moors, E. J., Troch, P. A., and Verburg, P. H.: Effects of land use changes on streamflow generation in the Rhine basin, Water Resour. Res., 45, W06405, doi:10.1029/2008WR007574, 2009.

Iglesias, A., Moneo, M., and Quiroga, S.: Methods for Evaluating Social Vulnerability to Drought, edited by: Iglesias, A., Garrote, L., Cancelliere, A., Cubillo, F., and Wilhite, D., Coping with Drought Risk in Agriculture and Water Supply Systems, Chapter 10, Adv. Nat. Technol. Hazards Res., 26, 153-159, 2009.

IPCC: Managing the Risks of Extreme Events and Disasters to Advance Climate Change Adaptation. A Special Report of Working Groups I and II of the Intergovernmental Panel on Climate Change, edited by: Field, C. B., Barros, V., Stocker, T. F., Qin, D., Dokken, D. J., Ebi, K. L., Mastrandrea, M. D., Mach, K. J., Plattner, G.-K., Allen, S. K., Tignor, M., and Midgley, P. M., Cambridge University Press, Cambridge, UK, and New York, NY, USA, 582 pp., 2012.

Jenerette, G. D., Barron-Gafford, G. A., Guswa, A. J., McDonnell, J. J., and Villegas, J. C.: Organization of complexity in water limited ecohydrology. Ecohydrology, 5, 184-199, 2012.

Kasprzyk, J. R., Reed, P. M., Kirsch, B. R., and Characklis, G. W.: Managing population and drought risks using many-objective water portfolio planning under uncertainty, Water Resour. Res., 45, W12401, doi:10.1029/2009WR008121, 2009. 
Kingston, D. G., Stagge, J. H., Tallaksen, L. M., and Hannah, D. M.: European-Scale Drought: Understanding Connections between Atmospheric Circulation and Meteorological Drought Indices, J. Climate, 28, 505-516, 2015.

Knutson, C. L., Hayes, M. J., and Philipps, T.: How to Reduce Drought Risk, Western Drought Coordination Council, Preparedness and Mitigation Working Group, Lincoln, 10 pp., available at: http://drought.unl.edu/portals/0/docs/risk.pdf (last access: 18 May 2016), 1998.

Kreibich, H., Vorogushyn, S., Aerts, J. C. J. H., Apel, H., Aronica, G. T., Arnbjerg-Nielsen, K., Di Baldassarre, G., Bouwer, L. M., Bubeck, Ph., Caloiero, T., Chinh, D. T., Cortés, M., Gain, A. K., Giampá, V., Kuhlicke, Ch., Kundzewicz, Z. W., Llasat, M. C., Mård, J., Matczak, P., Mazzoleni, M., Molinari, D., Dung, V. N., Petrucci, O., Schröter, K., Slager, K., Thieken, A. H., Ward, P. J., and Merz, B.: Reducing flood risk by learning from past events, under review, 2016.

Kuil, L., Carr, G., Viglione, A., and Bloeschl, G.: Conceptualizing the dynamics of a drought affected agricultural community, Geophys. Res. Abstr. Vol. 17, EGU2015-12435, EGU General Assembly 2015, 2015.

Kumar, R., Musuuza, J. L., Van Loon, A. F., Teuling, A. J., Barthel, R., Ten Broek, J., Mai, J., Samaniego, L., and Attinger, S.: Multiscale evaluation of the Standardized Precipitation Index as a groundwater drought indicator, Hydrol. Earth Syst. Sci., 20, 1117-1131, doi:10.5194/hess-20-1117-2016, 2016.

Lackstrom, K., Brennan, A., Ferguson, D., Crimmins, M., Darby, L., Dow, K., Ingram, K., Meadow, A., Reges, H., Shafer, M., and Smith, K.: The Missing Piece: Drought Impacts Monitoring. Workshop report produced by the Carolinas Integrated Sciences and Assessments program and the Climate Assessment for the Southwest, 5-6 March 2013, Tucson, AZ, 1-23, 22 pp., 2013.

Lake, S.: Drought and Aquatic Ecosystems: effects and responses, Wiley, Chichester, 400 pp., 2011.

Lehner, B., Döll, P., Alcamo, J., Henrichs, T., and Kaspar, F.: Estimating the impact of global change on flood and drought risks in Europe: a continental, integrated analysis, Clim. Change, 75, 273-299, 2006.

Lerner, D. N.: Groundwater recharge in urban areas, Atmos. Environ. 24, 29-33, 1990.

Lewis, S. L., and Maslin, M. A.: Defining the Anthropocene. Nature, 519(7542), 171-180, 2015.

Linton, J. and Budds, J.: The hydrosocial cycle: Defining and mobilizing a relational-dialectical approach to water, Geoforum, 57, 170-180, 2014.

Lloyd-Hughes, B.: The impracticality of a universal drought definition, Theor. Appl. Climatol., 117, 607-611, 2014.

Lobell, D. B., Burke, M. B., Tebaldi, C., Mastrandrea, M. D., Falcon, W. P., and Naylor, R. L.: Prioritizing climate change adaptation needs for food security in 2030, Science, 319, 607-610, 2008.

López-Moreno, J. I., Vicente-Serrano, Beguerıá, S. M., GarcıáRuiz, J. M., Portela, M. M., and Almeida, A. B.: Dam effects on droughts magnitude and duration in a transboundary basin: The Lower River Tagus, Spain and Portugal, Water Resour. Res., 45, W02405, doi:10.1029/2008WR007198, 2009.

Loucks, D. P.: Debates - Perspectives on sociohydrology: Simulating hydrologic-human interactions, Water Resour. Res., 51, 4789-4794, 2015.
Lucero, L. J.: The collapse of the Classic Maya: A case for the role of water control, Am. Anthropol., 104, 814-826, 2002.

Maggioni, E.: Water demand management in times of drought: What matters for water conservation, Water Resour. Res., 511, 125-139, 2015.

Maliva, R. and Missimer, T.: Aridity and drought, in: Arid lands water evaluation and management, 21-39, Springer Berlin Heidelberg, 2012.

Martinez, F., Di Baldassarre, G., and Zalantari, Z.: Modeling the Interactions between Hydrological Extremes, Water Management and Society, Geophys. Res. Abstr., 18, EGU2016-825, 2016.

Mateo, C. M., Hanasaki, N., Komori, D., Tanaka, K., Kiguchi, M., Champathong, A., Sukhapunnaphan, T., Yamazaki, D., and Oki, T.: Assessing the impacts of reservoir operation to floodplain inundation by combining hydrological, reservoir management, and hydrodynamic models, Water Resour. Res., 50, 7245-7266, doi:10.1002/2013wr014845, 2014.

McLeman, R., Dupre, J., Ford, L., Ford, J., Gajewski, K., and Marchildon, G.: What we learned from the Dust Bowl: lessons in science, policy, and adaptation, Popul. Environ., 35, 417-440, doi:10.1007/s11111-013-0190-z, 2014.

McMillan, H., Montanari, A., Cudennec, C., Savenije, H., Kreibich, H., Krueger, T., Liu, J., Mejia, A., Van Loon, A.F., Aksoy, H., Di Baldassarre, G., Huang, Y., Mazvimavi, D., Rogger, M., Sivakumar, B., Bibikova, T., Castellarin, A., Chen, Y., Finger, D., Gelfan, A., Hannah, D., Hoekstra, A., Li, H., Maskey, S., Mathevet, T., Mijic, A., Pedrozo Acuña, A., Polo, M., Rosales, V., Smith, P., Viglione, A., Srinivasan, V., Toth, E., van Nooyen, R., and Xia, J.: Panta Rhei 2013-2015: global perspectives on hydrology, society and change, Hydrol. Sci. J., 1-18, doi:10.1080/02626667.2016.1159308, 2016.

Mekonnen, M. M. and Hoekstra, A. Y.: Four billion people facing severe water scarcity, Sci. Adv., 2, e1500323, doi:10.1126/sciadv.1500323, 2016.

Mera, R., Massey, N., Rupp, D., Mote, P., Allen, M., and Frumhoff, P.: Climate change, climate justice and the application of probabilistic event attribution to summer heat extremes in the California Central Valley, Clim. Change, 133, 427-438, doi:10.1007/s10584-015-1474-3, 2014.

Mondal, A. and Mujumdar, P. P.: Return levels of hydrologic droughts under climate change, Adv. Water Resour., 75, 67-79, 2015.

Montanari, A., Young, G., Savenije, H. H. G., Hughes, D., Wagener, T., Ren, L. L., Koutsoyiannis, D., Cudennec, C., Toth, E., Grimaldi, S., Blöschl, G., Sivapalan, M., Beven, K., Gupta, H., Hipsey, M., Schaefli, B., Arheimer, B., Boegh, E., Schymanski, S. J., Di Baldassarre, G., Yu, B., Hubert, P., Huang, Y., Schumann, A., Post, D., Srinivasan, V., Harman, C., Thompson, S., Rogger, M., Viglione, A., McMillan, H., Characklis, G., Pang, Z., and Belyaev, V.: "Panta Rhei - Everything Flows": Change in hydrology and society - The IAHS Scientific Decade 20132022, Hydrol. Sci. J., 58, 1256-1275, 2013.

Mosely, L. M.: Drought impacts on the water quality of freshwater systems: a review, Earth Sci. Rev., 140, 203-214, 2015.

Nazemi, A. and Wheater, H. S.: On inclusion of water resource management in Earth system models - Part 1: Problem definition and representation of water demand, Hydrol. Earth Syst. Sci., 19, 33-61, doi:10.5194/hess-19-33-2015, 2015a. 
Nazemi, A. and Wheater, H. S.: On inclusion of water resource management in Earth system models - Part 2: Representation of water supply and allocation and opportunities for improved modeling, Hydrol. Earth Syst. Sci., 19, 63-90, doi:10.5194/hess19-63-2015, 2015b.

Obrien, L. V., Berry, H. L., Coleman, C., and Hanigan, I. C.: Drought as a mental health exposure, Environ. Res., 131, 181187, 2014.

Oertel, M., Meza, F. J., and Gironás, J. Improving operational drought definitions - taking them to basin scale, in: Drought: Research and Science-Policy Interfacing, edited by: Andreu, J., Solera, A., Paredes-Arquiola, J., Haro-Monteagudo, D., and van Lanen, H. A. J., CRC Press, London, 151, doi:10.1201/b1807726, 2015.

Oki, T. and Kanae, S.: Global hydrological cycles and world water resources, Science, 313, 1068-1072, 2006.

Palmer, W. C.: Meteorological drought (Vol. 30). Washington, DC, USA, US Department of Commerce, Weather Bureau, 1965.

Pearce, R., Dessai, S., and Barr, S.: Re-Framing Environmental Social Science Research for Sustainable Water Management in a Changing Climate, Water Resour. Manage., 27, 959-979, 2013.

Pérez Blanco, C. D. and Gómez, C. M.: Insuring water: A practical risk management option in water scarce and drought-prone regions, Water Pol., 16, 244-263, 2014.

Pokhrel, Y. N., Hanasaki, N., Yeh, P. J. F., Yamada, T. J., Kanae, S., and Oki, T.: Model estimates of sea-level change due to anthropogenic impacts on terrestrial water storage, Nature Geosci., 5, 389-392, doi:10.1038/ngeo1476, 2012.

Price, K., Jackson, C. R., Parker, A. J., Reitan, T., Dowd, J., and Cyterski, M. Effects of watershed land use and geomorphology on stream low flows during severe drought conditions in the southern Blue Ridge Mountains, Georgia and North Carolina, United States, Water Resour. Res., 47, W02516, doi:10.1029/2010WR009340, 2011.

Prosdocimi, I., Kjeldsen, T. R., and Miller, J. D.: Detection and attribution of urbanization effect on flood extremes using nonstationary flood frequency models, Water Resour. Res., 51, 4244-4262, 2015.

Prudhomme C., Giuntoli, I., Robinson, E. L., Clark, D. B., Arnell, N. W., Dankers, R., Fekete, B. M., Franssen, W., Gerten, D., Gosling, S. N., Hagemann, S., Hannah, D. M., Kim, H., Masaki, Y., Satoh, Y., Stacke, T., Wada, Y., and Wisser, D.: Hydrological droughts in the 21st century, hotspots and uncertainties from a global multimodel ensemble experiment, P. Natl. Acad. Sci. USA, 111, 3262-3267, doi:10.1073/pnas.1222473110, 2014.

Pullinger, M., Anderson, B., Browne, A., and Medd, W.: New directions in understanding household water demand: a practices perspective, J. Water Supply, 62, 496-506, 2013.

Querner, E., Morábito, J., and Tozzi, D.: SIMGRO, a GISSupported Regional Hydrologic Model in Irrigated Areas: Case Study in Mendoza, Argentina, J. Irrig. Drain Eng., 134, 43-48, 2008

Rangecroft, S., Van Loon, A. F., Maureira, H., Verbist, K., and Hannah, D. M.: Multi-method assessment of dam effects on hydrological droughts in arid Chile, submitted, 2016.

Rijkswaterstaat: Droogtemonitor, available at http://www.rijkswaterstaat.nl/water/waterdata-enwaterberichtgeving (last access: 18 May 2016), 2015.
Rijsberman, F. R.: Water scarcity: Fact or fiction?, Agr. Water Manage., 80, 5-22, 2006.

Rodriguez-Iturbe, I., Porporato, A., Laio, F., and Ridolfi, L.: Plants in water-controlled ecosystems: active role in hydrologic processes and response to water stress: I. Scope and general outline, Adv. Water Resour., 24, 695-705, 2001.

Sadri, S., Kam, J., and Sheffield, J.: Nonstationarity of low flows and their timing in the eastern United States, Hydrol. Earth Syst. Sci., 20, 633-649, doi:10.5194/hess-20-633-2016, 2016.

Savenije, H. H. G.: Water scarcity indicators; the deception of the numbers, Phys. Chem. Earth, 25, 199-204, 2000.

Sheffield, J. and Wood, E.: Drought; Past Problems and Future Scenarios, Earthscan, London, UK, Washington DC, USA, 233 pp., 2011.

Sheffield, J., Wood, E. F., and Roderick, M. L.: Little change in global drought over the past 60 years, Nature, 491, 435-438, doi:10.1038/nature11575, 2012.

Sheffield, J., Wood, E. F., Chaney, N., Guan, K., Sadri, S., Yuan, X., Olang, L., Amani, A., Ali, A., Demuth, S., and Ogallo, L.: A drought monitoring and forecasting system for sub-Sahara African water resources and food security, B. Am. Meteor. Soc., 95, 861-882, doi: 10.1175/BAMS-D-12-00124.1, 2014.

Shukla, S. and Wood, A. W.: Use of a standardized runoff index for characterizing hydrologic drought, Geophys. Res. Lett., 35, L02405, doi:10.1029/2007GL032487, 2008.

Sivapalan, M., Savenije, H. H., and Blöschl, G.: Socio-hydrology: A new science of people and water, Hydrol. Process., 26, 1270 1276, 2012.

Smit, B., Burton, I., Klein, R. J., and Wandel, J.: An anatomy of adaptation to climate change and variability, Clim. Change, 45, 223-251, 2000.

Stagge, J. H., Kohn, I., Tallaksen, L. M., and Stahl, K.: Modeling drought impact occurrence based on meteorological drought indices in Europe, J. Hydrol., 530, 37-50, 2015 a.

Stagge, J. H., Tallaksen, L. M., Gudmundsson, L., Van Loon, A. F., and Stahl, K.: Candidate distributions for climatological drought indices (SPI and SPEI), Int. J. Climatol., 35, 4027-4040, doi:10.1002/joc.4267, 2015 b.

Stahl, K., Hisdal, H., Hannaford, J., Tallaksen, L. M., van Lanen, H. A. J., Sauquet, E., Demuth, S., Fendekova, M., and Jódar, J.: Streamflow trends in Europe: evidence from a dataset of nearnatural catchments, Hydrol. Earth Syst. Sci., 14, 2367-2382, doi:10.5194/hess-14-2367-2010, 2010

Stahl, K., Kohn, I., Blauhut, V., Urquijo, J., De Stefano, L., Acácio, V., Dias, S., Stagge, J. H., Tallaksen, L. M., Kampragou, E., and Van Loon, A. F.: Impacts of European drought events: insights from an international database of text-based reports, Hydrol. Earth Syst. Sci., 16, 801-819, doi:10.5194/hess-16-8012016, 2016.

Stahl, K., Kohn, I., De Stefano, L., Tallaksen, L. M., Rego, F. C., Seneviratne, S. I., Andreu, J., and Van Lanen, H. A. J.: An impact perspective on pan-European drought sensitivity, in: Drought: Research and Science-Policy Interfacing, edited by: Andreu, J., Solera, A., Paredes-Arquiola, J., Haro-Monteagudo, D., and van Lanen, H. A. J., CRC Press, London, 329-334, doi:10.1201/b18077-56, 2015.

Stanke, C., Kerac, M., Prudhomme, C., Medlock, J., and Murray, V.: Health Effects of Drought: a Systematic Review of the Evidence, PLoS Currents, 5, 
doi:10.1371/currents.dis.7a2cee9e980f91ad7697b570bcc4b004, 2013.

Staudinger, M., Stahl, K., and Seibert, J.: A drought index accounting for snow, Water Resour. Res., 5, 7861-7872, doi:10.1002/2013WR015143, 2014.

Stoelzle, M., Stahl, K., Morhard, A., and Weiler, M.: Streamflow sensitivity to drought scenarios in catchments with different geology, Geophys. Res. Lett., 41, 6174-6183, doi:10.1002/2014GL061344, 2014.

Tallaksen, L. M. and Van Lanen, H. A. J. (Eds.): Hydrological drought: processes and estimation methods for streamflow and groundwater, Developments in water science, 48, Elsevier Science B.V., Amsterdam, the Netherlands, 2004.

Tallaksen, L. M.: Modelling land use change effects on low flows, FRIEND, 1, 56-68, 1993.

Teuling, A. J., Van Loon, A. F., Seneviratne, S. I., Lehner, I., Aubinet, M., Heinesch, B., Bernhofer, C., Grünwald, T., Prasse, H., and Spank, U.: Evapotranspiration amplifies European summer drought, Geophys. Res. Lett., 40, 2071-2075, doi:10.1002/grl.50495, 2013.

Thompson, S. E., Sivapalan, M., Harman, C. J., Srinivasan, V., Hipsey, M. R., Reed, P., Montanari, A., and Blöschl, G.: Developing predictive insight into changing water systems: useinspired hydrologic science for the Anthropocene, Hydrol. Earth Syst. Sci., 17, 5013-5039, doi:10.5194/hess-17-50132013, 2013.

Trambauer, P., Werner, M., Winsemius, H. C., Maskey, S., Dutra, E., and Uhlenbrook, S.: Hydrological drought forecasting and skill assessment for the Limpopo River basin, southern Africa, Hydrol. Earth Syst. Sci., 19, 1695-1711, doi:10.5194/hess-191695-2015, 2015.

Trenberth, K. E., Dai, A., van der Schrier, G., Jones, P. D., Barichivich, J., Briffa, K. R., and Sheffield, J. Global warming and changes in drought, Nature Clim. Change, 4, 17-22, 2014.

Tuinenburg, O. A., Hutjes, R. W. A., Stacke, T., Wiltshire, A., and Lucas-Picher, P.: Effects of Irrigation in India on the Atmospheric Water Budget, J. Hydrometeorol., 15, 1028-1050, doi:10.1175/JHM-D-13-078.1, 2014.

Van Dijk, A. I. J. M., Kirby, M., Paydar, Z., Podger, G., Mainuddin, M. D., Marvanek, S., and Peña Arancibia, J.: Uncertainty in river modelling across the Murray-Darling Basin, A report to the Australian Government from the CSIRO Murray-Darling Basin Sustainable Yields Project, details published by CSIRO, 2008.

Van Dijk, A. I. J. M., Beck, H. E., Crosbie, R. S., Jeu, R. A., Liu, Y. Y., Podger, G. M., and Viney, N. R.: The Millennium Drought in southeast Australia (2001-2009): Natural and human causes and implications for water resources, ecosystems, economy, and society, Water Resour. Res., 49, 1040-1057, 2013.

Van Huijgevoort, M. H. J., Van Lanen, H. A. J., Teuling, A. J., and Uijlenhoet, R.: Identification of changes in hydrological drought characteristics from a multi-GCM driven ensemble constrained by observed discharge, J. Hydrol., 512, 421-434, doi:10.1016/j.jhydrol.2014.02.060, 2014.

Van Lanen, H. A. J., Kasparek, L., Novicky, O., Querner, E. P., Fendekova, M. Kupczyk, E.: Human influences, Ch. 9, in: Hydrological drought: processes and estimation methods for streamflow and groundwater, edited by: Tallaksen, L. M., and Van Lanen, H. A. J., Developments in water science, 48, Elsevier Science B.V., Amsterdam, the Netherlands, 2004.
Van Lanen, H. A. J., Laaha, G., Kingston, D. G., Gauster, T., Ionita, M., Vidal, J.-P., Vlnas, R., Tallaksen, L. M., Stahl, K., Hannaford, J., Delus, C., Fendekova, M., Mediero, L., Prudhomme, C., Rets, E., Romanowicz, R. J., Gailliez, S., Wong, W. K., Adler, M.-J., Blauhut, V., Caillouet, L., Chelcea, S., Frolova, N., Gudmundsson, L., Hanel, M., Haslinger, K., Kireeva, M., Osuch, M., Sauquet, E., Stagge, J. H., and Van Loon, A. F.: Hydrology needed to manage droughts: the 2015 European case, Hydrol. Process., 30, 3097-3104, doi:10.1002/hyp.10838, 2016.

Van Loon, A. F.: Hydrological drought explained, Wiley Interdisciplinary Reviews: Water, 2, 359-392, 2015.

Van Loon, A. F. and Laaha, G.: Hydrological drought severity explained by climate and catchment characteristics, J. Hydrol., 526, 3-14, 2015.

Van Loon, A. F. and Van Lanen, H. A. J.: A process-based typology of hydrological drought, Hydrol. Earth Syst. Sci., 16, 19151946, doi:10.5194/hess-16-1915-2012, 2012.

Van Loon, A. F. and Van Lanen, H. A. J.: Making the distinction between water scarcity and drought using an observation-modeling framework, Water Resour. Res., 49, 1483-1502, 2013.

Van Loon, A. F. and Van Lanen, H. A. J.: Testing the observationmodelling framework to distinguish between hydrological drought and water scarcity in case studies around Europe, Europ. Water, 49, 65-75, 2015.

Van Loon, A. F., Ploum, S. W., Parajka, J., Fleig, A. K., Garnier, E., Laaha, G., and Van Lanen, H. A. J.: Hydrological drought types in cold climates: quantitative analysis of causing factors and qualitative survey of impacts, Hydrol. Earth Syst. Sci., 19, 1993-2016, doi:10.5194/hess-19-1993-2015, 2015.

Van Loon, A. F., Gleeson, T., Clark, J., Van Dijk, A. I. J. M., Stahl, K., Hannaford, J., Di Baldassarre, G., Teuling, A. J., Tallaksen, L. M., Uijlenhoet, R., Hannah, D. M., Sheffield, J., Svoboda, M., Verbeiren, B., Wagener, T., Rangecroft, S., Wanders, N., and Van Lanen, H. A. J.: Drought in the Anthropocene, Nature Geosci., 9, 89-91, doi:10.1038/ngeo2646, 2016.

Van Oel, P. R., Krol, M. S., and Hoekstra, A. Y.: Application of multi-agent simulation to evaluate the influence of reservoir operation strategies on the distribution of water availability in the semi-arid Jaguaribe basin, Brazil, Phys. Chem. Earth, 47, 173181, 2012.

Van Vliet, M. T. H. and Zwolsman, J. J. G.: Impact of summer droughts on the water quality of the Meuse river, J. Hydrol., 353, $1-17,2008$.

Veldkamp, T. I., Wada, Y., de Moel, H., Kummu, M., Eisner, S., Aerts, J. C., and Ward, P. J.: Changing mechanism of global water scarcity events: Impacts of socioeconomic changes and interannual hydro-climatic variability, Global Environ. Change, 32, 18-29, 2015.

Verbeiren, B., Huysmans, M., Tychon, B., Jacquemin, I., Canters, F., Vanderhaegen, S., Engelen, G., Poelmans, L., De Becker, P., Tsakiris, G., Vangelis, H., and Batelaan, O.: Drought-related vulnerability and risk assessment of groundwater resources under temperate conditions, Conference Proceedings, 13th International Conference on Environmental Science and Technology Athens, Greece, 5-7 September 2013, 2013.

Vicente-Serrano, S. M., Beguería, S., Lorenzo-Lacruz, J., Camarero, J. J., López-Moreno, J. I., Azorin-Molina, C., Revuelto, J., Morán-Tejeda, E., and Sanchez-Lorenzo, A.: Performance of 
drought indices for ecological, agricultural, and hydrological applications, Earth Interact., 16, 1-27, 2012.

Vicente-Serrano, S. M., Gouveia, C., Camarero, J. J., Beguería, S., Trigo, R., López-Moreno, J. I., Azorín-Molina, C., Pasho, E., Lorenzo-Lacruz, J., Revuelto, J., and Morán-Tejeda, E.: Response of vegetation to drought time-scales across global land biomes, P. Natl. Acad. Sci., 110, 52-57, 2013.

Vidal, J.-P., Martin, E., Kitova, N., Najac, J., and Soubeyroux, J.M.: Evolution of spatio-temporal drought characteristics: validation, projections and effect of adaptation scenarios, Hydrol. Earth Syst. Sci., 16, 2935-2955, doi:10.5194/hess-16-29352012, 2012.

Viglione, A., Di Baldassarre, G., Brandimarte, L., Kuil, L., Carr, G., Salinas, J. L., and Blöschl, G.: Insights from socio-hydrology modelling on dealing with flood risk-roles of collective memory, risk-taking attitude and trust, J. Hydrol., 518, 71-82, 2014.

Vogel, R. M., Lall, U., Cai, X., Rajagopalan, B., Weiskel, P., Hooper, R. P., and Matalas, N. C.: Hydrology: The interdisciplinary science of water, Water Resour. Res., 51, 4409-4430, 2015

Vorogushyn, S. and Merz, B.: Flood trends along the Rhine: the role of river training, Hydrol. Earth Syst. Sci., 17, 3871-3884, doi:10.5194/hess-17-3871-2013, 2013.

Vörösmarty, C. J., Green, P., Salisbury, J., and Lammers, R. B.: Global water resources: vulnerability from climate change and population growth, Science, 289, 284-288, 2000.

Vörösmarty, C. J., Lettenmaier, D., Leveque, C., Meybeck, M., Pahl-Wostl, C., Alcamo, J., and Naiman, R.: Humans transforming the global water system, Eos, Trans. Am. Geophys. Union, 85, 509-514, 2004.

Vörösmarty, C. J., Hoekstra, A. Y., Bunn, S. E., Conway, D., and Gupta, J.: Fresh water goes global, Science, 349, 478-479, 2015.

Vörösmarty, C. J., McIntyre, P. B., Gessner, M. O., Dudgeon, D., Prusevich, A., Green, P., Glidden, S., Bunn, S. E., Sullivan, C. A., Reidy Liermann, C., and Davies, P. M.: Global threats to human water security and river biodiversity, Nature, 467, 555-561, doi:10.1038/nature09440, 2010.

Wada, Y., Van Beek, L. P. H., Viviroli, D., Dürr, H. H., Weingartner, R., and Bierkens, M. F. P.: Global monthly water stress: 2. Water demand and severity of water stress, Water Resour. Res., 47, W07518, doi:10.1029/2010WR009792, 2011.

Wada, Y., van Beek, L. P. H., Wanders, N., and Bierkens, M. F. P.: Human water consumption intensifies hydrological drought worldwide, Environ. Res. Lett., 8, 034036, doi:10.1088/17489326/8/3/034036, 2013.

Wagener, T., Sivapalan, M., Troch, P., and Woods, R.: Catchment Classification and Hydrologic Similarity, Geogr. Compass, 1, 901-931, doi:10.1111/j.1749-8198.2007.00039.x, 2007.

Wagener, T., Sivapalan, M., Troch, P. A., McGlynn, B. L., Harman, C. J., Gupta, H. V., and Wilson, J. S.: The future of hydrology: An evolving science for a changing world. Water Resour. Res., 46, W05301, doi:10.1029/2009WR008906, 2010.
Wanders, N. and Wada, Y.: Human and climate impacts on the 21st century hydrological drought, J. Hydrol., 526, 208-220, doi:10.1016/j.jhydrol.2014.10.047, 2015.

Wanders, N., Wada, Y., and Van Lanen, H. A. J.: Global hydrological droughts in the 21 st century under a changing hydrological regime, Earth Syst. Dynam., 6, 1-15, doi:10.5194/esd-6-1-2015, 2015.

Watts, G., von Christierson, B., Hannaford, J., and Lonsdale, K.: Testing the resilience of water supply systems to long droughts, J. Hydrol., 414, 255-267, 2012.

Whitfield, P. H., Burn, D. H., Hannaford, J., Higgins, H., Hodgkins, G. A., Marsh, T., and Looser, U.: Reference hydrologic networks I. The status and potential future directions of national reference hydrologic networks for detecting trends, Hydrol. Sci. J., 57, 1562-1579, 2012.

Wilhite, D. A. and Vanyarkho, O.: Pervasive impacts of a creeping phenomenon, in: Drought: A Global Assessment I, edited by: Wilhite, D. A., Routledge, New York/London, 245-255, 2000.

Wilhite, D. A. and Glantz, M. H.: Understanding: the drought phenomenon: the role of definitions, Water Int., 10, 111-120, 1985.

Wilhite, D. A. and Buchanan-Smith, M.: Drought as hazard: understanding the natural and social context. Drought and Water Crises - Science, Technology and Management issues, Taylor \& Francis, 2005.

Williams, A. P., Seager, R., Abatzoglou, J. T., Cook, B. I., Smerdon, J. E., and Cook, E. R.: Contribution of anthropogenic warming to California drought during 2012-2014, Geophys. Res. Lett., 42, 6819-6828, doi:10.1002/2015GL064924, 2015.

Winter, T. C., Harvey, J. W., Franke, O. L., and Alley, W. M.: Ground water and surface water: A single resource. USGS Circular 1139, available at: http://pubs.usgs.gov/circ/circ1139/index. html (last access: 18 May 2016), 1998.

Wisser, D., Fekete, B. M., Vörösmarty, C. J., and Schumann, A. H.: Reconstructing 20th century global hydrography: a contribution to the Global Terrestrial Network- Hydrology (GTN-H), Hydrol Earth Syst. Sci., 14, 1-24, doi:10.5194/hess-14-1-2010, 2010.

Wood, E. F., Roundy, J. K., Troy, T. J., Van Beek, L. P. H., Bierkens, M. F., Blyth, E., and Whitehead, P: Hyperresolution global land surface modeling: Meeting a grand challenge for monitoring Earth's terrestrial water, Water Resour. Res., 47, W05301, doi:10.1029/2010WR010090, 2011.

Yevjevich, V. M.: An objective approach to definitions and investigations of continental hydrologic droughts. Hydrol. Pap., Colorado State University, no. 23, 25 pp., 1967.

Yevjevich, V. M.: Floods and society, Coping with Floods, 3-9, Springer, the Netherlands, 1994. 